medRxiv preprint doi: https://doi.org/10.1101/2020.07.24.20161851; this version posted July 27, 2020. The copyright holder for this preprint

(which was not certified by peer review) is the author/funder, who has granted medRxiv a license to display the preprint in perpetuity.

It is made available under a CC-BY-ND 4.0 International license.

Trends in Angiotensin Receptor Blocker Use Among those at Risk for COVID-19 Morbidity and Mortality in the United States

Alexandra Perez, Pharm.D., M.S.

Associate professor

Department of Sociobehavioral and Administrative Pharmacy

Nova Southeastern University College of Pharmacy

3200 S. University Dr.

Davie, FL 33328

Email: alperez@,nova.edu

Robert Speth, Ph.D., FAAAS

Professor, Department of Pharmaceutical Sciences

Nova Southeastern University College of Pharmacy

3200 S. University Dr.

Davie, FL 33328

Email:rs1251@nova.edu

Adjunct Professor, Department of Pharmacology and Physiology

Georgetown University School of Medicine

3900 Reservoir Road, N.W.

Washington, D.C. 20057

Juan Saavedra, M.D.

Adjunct Professor, Department of Pharmacology and Physiology

Georgetown University Medical Center

3900 Reservoir Road, N.W. Bldg. D, Room 287.

Washington, D.C. 20057

Telephone 301-910-5505

Email: juan.saavedra@georgetown.edu

Running title: ARB use for COVID-19 comorbidities 
medRxiv preprint doi: https://doi.org/10.1101/2020.07.24.20161851; this version posted July 27, 2020. The copyright holder for this preprint

(which was not certified by peer review) is the author/funder, who has granted medRxiv a license to display the preprint in perpetuity.

It is made available under a CC-BY-ND 4.0 International license .

\section{Trends in Angiotensin Receptor Blocker Use Among those at Risk for COVID-19 Morbidity and Mortality in the United States}

\section{Key Points}

Question: What is the prevalence of angiotensin receptor blocker (ARB) use among individuals at higher risk of COVID-19-related complications?

Findings: In a cross-sectional study with data from 39,749 adult participants of the National Health and Nutrition Examination Survey, ARB use ranged between 7.4\% and 26.2\% among those with one or two respiratory, metabolic, renal and/or cardiovascular diseases. Significant disparities in ARB use were found in participants with preexisting conditions and sociodemographic factors that place them at a higher risk of COVID-19 morbidity and mortality.

Meaning: ARB use is widespread and disproportionate in the United States among people at higher risk of COVID-19 complications.

\footnotetext{
ABSTRACT

Importance: Assessment of the use of angiotensin receptor blockers (ARBs) in the United States provides insight into prescribing practices, and may inform guidelines, policy measures and research during the COVID-19 pandemic.

Objective: To evaluate trends in ARB use among adults in the United States who have preexisting conditions and sociodemographic risk factors that put them at a higher risk of SARS-CoV-2 infection and COVID-19-related complications and mortality.

Design, setting and participants: This study uses the nationally representative cross-sectional data from the 2005-2018 National Health and Nutrition Examination Survey (NHANES). Participants included 39,749 non-institutionalized U.S. civilian adults who were 20 years and older and those with the most common preexisting conditions and risk factors reported among patients with COVID-19.

Main outcomes and measures: Use of ARBs in the prior 30 days from survey interview.

Results: ARB use ranged from 7.4\% [95\% CI, 6.5\%-8.4\%] to $26.2 \%$ [95\% CI, 19.4\%-34.4\%] among those with one or two metabolic, renal, respiratory, and/or cardiovascular diseases. Among individuals with the three most common preexisting conditions in patients with COVID-19 including hypertension, diabetes and obesity, ARB use was higher among the elderly, females, non-Hispanic whites, and those with health insurance coverage.
} 
medRxiv preprint doi: https://doi.org/10.1101/2020.07.24.20161851; this version posted July 27, 2020. The copyright holder for this preprint

(which was not certified by peer review) is the author/funder, who has granted medRxiv a license to display the preprint in perpetuity.

It is made available under a CC-BY-ND 4.0 International license .

Conclusions and relevance: In this nationally representative survey, ARB use was found to be widespread, but unevenly distributed among individuals with conditions and sociodemographic risk factors that place them at a higher risk of COVID-19 morbidity and mortality.

\section{INTRODUCTION}

The COVID-19 pandemic affects not only the lung but multiple organs ${ }^{1-7}$ with high individual variability, in some cases with devastating consequences, leading to chronic disability or death. ${ }^{8,9}$ At the present time, no therapies have been devised to prevent or treat all cases of SARS-CoV-2 infection leading to COVID19, however, a large number of therapeutic approaches have been proposed and several have been reported to have incremental benefits. ${ }^{10-14}$ Thus, it is imperative to identify available compounds that could be repurposed as beneficial, or at the very least palliative, to prevent or ameliorate the severity of the disease.

Some preexisting disorders such as hypertension, cardiovascular and kidney disease, diabetes, and obesity, are frequently comorbid with COVID-19. ${ }^{15-24}$ These disorders are characterized by enhanced activity of the Renin-Angiotensin System (RAS), in particular, with excessive stimulation of the Angiotensin (Ang) II AT1 receptor (AT1R) type. ${ }^{25}$ Increased AT1R activity leads to reduced systemic and pulmonary blood flow and oxygen levels, pathological inflammation, fibrosis, reduced sensitivity to insulin, alterations in innate and adaptive immunity, and coagulation defects. ${ }^{26-28}$ This explains why these preexisting conditions significantly increase the risk of poor outcome and death in COVID-19 patients.

It is not surprising that patients afflicted with these illnesses are frequently treated with medications such as Angiotensin Receptor Blockers (ARBs) that antagonize the pathological effects of AT1R hyperactivity. ${ }^{29-32}$ For these reasons, many patients afflicted with COVID-19 comorbidities and infected by SARS-CoV-2 have been previously treated with ARBs at the time of their diagnoses.

Although the use of ARBs for the treatment of hypertension, cardiovascular and metabolic disorders is widespread, data describing the precise prevalence of these medications in risk groups with comorbidities of COVID-19 is lacking. Such data are essential to address the question of the expected number of individuals treated with ARBs in the general population as well as at the time of SARS-CoV-2-infection. The objective of this study is to estimate ARB trends in use among adults in the United States who have preexisting conditions and sociodemographic risk factors that put them at a higher risk of SARS-CoV-2 infection and COVID-19-related complications and mortality. These data will be useful to determine, in future population studies, whether ARB use influences SARS-CoV-2 infection rates, the development of symptoms, the severity of the illness, the prognosis of COVID-19, and the process of recovery. 
medRxiv preprint doi: https://doi.org/10.1101/2020.07.24.20161851; this version posted July 27, 2020. The copyright holder for this preprint

(which was not certified by peer review) is the author/funder, who has granted medRxiv a license to display the preprint in perpetuity.

It is made available under a CC-BY-ND 4.0 International license .

\section{METHODS}

Data Source and Study Population:

The National Health and Nutrition Examination Survey (NHANES) is a nationally representative crosssectional survey of the non-institutionalized civilian population in the United States. ${ }^{33}$ This survey consists of questionnaire, physical examination and laboratory components that includes self-reported data of medical history, prescription medication use, and body measures among others. This study used publicly available, deidentified data and did not require institutional review board approval (45 CFR $\S 46.102(\mathrm{f}))$.

We used data from adults 20 years of age or older and evaluated ARB use within the most prevalent (5\% or higher) preexisting conditions reported in the COVID-19 population. ${ }^{34}$ For this study, data were used from the 7 most recent NHANES biannual cycles being 2005 through 2018.

\section{Assessment of Angiotensin Receptor Blocker Use}

The prescription medications survey provides personal interview data on the use of prescription medications during a 30-day period prior to the participant's interview date. All prescription drugs are entered upon interview by generic name. ARB use was defined as use of any angiotensin receptor blocker (losartan, candesartan, olmesartan, azilsartan, eprosartan, irbesartan, telmisartan, and valsartan) either as a single agent or in combination with other drugs.

Statistical Analysis

This study assessed the prevalence of ARBs in the general adult population and within populations of hypertension, diabetes, coronary heart disease, stroke, kidney disease, congestive heart failure, obesity, asthma, and chronic obstructive pulmonary disease (COPD) as shown in Table 1. ARB use was also explored within select populations with 2 concomitant metabolic, renal and cardiovascular diseases and data are presented in eTable 1 in the Supplement. ARB use within NHANES biannual cycle was also assessed in the general adult population and within the previously specified conditions from 2005-2018 (Figure 1 and eTable 2 in the Supplement). Furthermore, the association of ARB use and commonly reported sociodemographic risk factors in those diagnosed with COVID-19 including age, gender, race/ethnicity, household income and educational levels, health and prescription insurance coverage and body mass index were explored within populations with hypertension, diabetes and obesity (defined as $\geq 30 \mathrm{~kg} / \mathrm{m}^{2}$ ) and are shown in Tables 2-4. These conditions are the three most prevalent comorbidities (30\% or higher) among those with COVID- $19 .{ }^{34}$ Similar analyses were conducted within populations with 
medRxiv preprint doi: https://doi.org/10.1101/2020.07.24.20161851; this version posted July 27, 2020. The copyright holder for this preprint (which was not certified by peer review) is the author/funder, who has granted medRxiv a license to display the preprint in perpetuity. It is made available under a CC-BY-ND 4.0 International license .

coronary heart disease, stroke, kidney disease and congestive heart failure and are presented in eTable 3 and eTable 4 in the Supplement. Sociodemographic risk factor heterogeneity was assessed by stratification of age ( $\leq 44,45-64$ and $\geq 65$ years), sex (male/female), race/ethnicity (non-Hispanic white, non-Hispanic black, Hispanic, and other race), income $(\geq \$ 20,000,<\$ 20,000)$, education (high school or lower, some college or higher), health insurance coverage (yes/no), prescription insurance coverage (yes/no) and body mass index $\left(\leq 24.99 \mathrm{~kg} / \mathrm{m}^{2}, 25-29.99 \mathrm{~kg} / \mathrm{m}^{2}, 30-39.99 \mathrm{~kg} / \mathrm{m}^{2}\right.$, and $\left.\geq 40 \mathrm{~kg} / \mathrm{m}^{2}\right)$. Prevalent ARB use was calculated within unique risk factor subgroups (e.g., within participants age $\leq 44$ ) and distribution across subgroups (e.g., across all age categories). Survey-weighted binomial logistic regression evaluated the association of ARB use, as the dependent variable, and biannual cycle, sociodemographic risk factors and body mass index categories were independent parameters. ARB use prevalence estimates were adjusted for oversampling of older adults, low-income individuals, and racial/ethnic minorities for their unequal sampling probability and nonresponse. Statistical significance was assessed at the 2 -sided $\alpha=0.05$ level. All analyses were conducted using IBM SPSS version 26.0.

\section{RESULTS}

Data from 39,749 participant adults aged 20 years and older were used in this study and the sample size for each biannual NHANES cycle ranged from 4979 to 6218 . Sample size for populations with hypertension, diabetes and obesity are presented in Tables 2-4. Response rates in NHANES cycles ranged between $71 \%$ and $94.3 \%{ }^{35}$ Table 1 shows the national count and percent of US adults reporting use of an ARB in the general adult population and within populations with select metabolic, respiratory, renal and cardiovascular diseases. $6.4 \%$ percent (or 14.4 million people) in the general adult population, regardless of comorbidities, in the US were estimated to be taking ARBs. In the single condition population analysis in Table 1, ARB use was at its lowest among those with asthma (7.4\% [95\% CI, 6.5\%-8.4\%, 2.4 million people]) and at its highest among those with diabetes (19.3\% [95\% CI, 17.8\%-20.9\%, 4.1 million people]). ARB use was more prevalent within populations with 2 co-existing chronic conditions. As shown in eTable 1 in the Supplement, ARB use prevalence was at its lowest in those with co-existing kidney disease and congestive heart failure $(18.7 \%$ [95\% CI, 12.8\%-26.5\%, 175,000 people] and at its highest among those with both coronary heart disease and kidney disease (26.2\% [95\% CI, 19.4\%-34.4\%, 197,000 people]).

Figure 1 reports a significant increase in the prevalence of ARB use from 2005 to 2018 in the general adult population $(4.5 \%$ [95\% CI, 3.6\%-5.6\%] in 2005-2006 and 7.6\% [95\% CI, $6.5 \%-8.8 \%$ ] in $2017-$ 2018, $\mathrm{p}$ for trend $=0.007)$. The same trend was observed among those with hypertension $(14.5 \%[95 \% \mathrm{CI}$, 11.7\%-17.7\%] in 2005-2006 and 21.8\% [95\% CI, 19.0\%-24.9\%] in 2017-2018, $\mathrm{p}$ for trend =0.005), and diabetes (11.3\% [95\% CI, 8.0\%-15.7\%] in 2005-2006 and 20.0\% [95\% CI, 16.7\%-23.7\%] in 2017-2018, 
medRxiv preprint doi: https://doi.org/10.1101/2020.07.24.20161851; this version posted July 27, 2020. The copyright holder for this preprint (which was not certified by peer review) is the author/funder, who has granted medRxiv a license to display the preprint in perpetuity.

It is made available under a CC-BY-ND 4.0 International license .

$\mathrm{p}$ for trend $=0.02)$ but not in those with obesity $(7.2 \%$ [95\% CI, 5.4\%-9.6\%] in 2005-2006 and 9.6\% [95\% CI, 8.1\%-11.2\%] in 2017-2018, p for trend $=0.12$ ). ARB use among participants with coronary heart disease, stroke, kidney disease, and congestive heart failure did not change across biannual cycles and data are shown in eTable 2 in the Supplement.

Tables 2-4 show the prevalence of ARB use by select sociodemographic risk factors and body mass index categories among those with hypertension, diabetes, and obesity. In these three populations, there was a significant association between ARB use and age groups ( $p<0.001$ for all), gender $(p<0.03$ for all), race/ethnicity ( $<<0.001$ for all), and health insurance coverage ( $p<0.001$ for all). In those with hypertension and diabetes, a significant association of ARB use and household income ( $<<0.01$ for both), educational level ( $p<0.04$ for both) and body mass index category ( $<<0.0001$ for both) was observed. Odds ratios in Tables 2-4 indicate that ARB use in those with hypertension, diabetes and obesity increased with age, was higher among females than males, non-Hispanic whites compared to minorities and in those with health insurance coverage. In those with hypertension and diabetes, ARB use was higher among those with household income $\geq \$ 20,000$, some college education or higher, and higher body mass index level. Prescription insurance coverage was not associated with ARB use in any of the populations evaluated. eTables 3 and eTable 4 in the Supplement show the prevalence of ARB use among participants with coronary heart disease, stroke, kidney disease, and congestive heart failure and show similar trends in ARB use within sociodemographic risk factors.

\section{DISCUSSION}

Our results demonstrate that ARB use is prevalent for conditions that increase the risk of SARS-CoV-2 infection and increase COVID-19 morbidity and mortality. ARB use in the United States in the general adult population is $6.4 \%$ and ranging between $7.4 \%$ and $26.2 \%$ among those with one or two metabolic, respiratory, renal and cardiovascular diseases prevalent in the COVID-19 population. Over time, ARB use has increased in the general population and among those with hypertension and diabetes but not in the other conditions evaluated. Overall, ARB use was most prevalent with increasing age, among females, non-Hispanic whites, those with health insurance coverage, and higher income, educational level and body mass index categories in many of the populations evaluated including hypertension, diabetes, obesity and other cardiovascular diseases.

Along with other antihypertensive agents, ARBs are currently indicated to be initial treatment for hypertension among non-Blacks and as secondary treatment for Blacks. ${ }^{36}$ However, ARBs or ACE inhibitors are recommended for treatment of hypertension in all patients with diabetes. ${ }^{36}$ ARBs are very well tolerated, including in the elderly, increasingly available in the therapeutic arsenal as generic drugs, 
medRxiv preprint doi: https://doi.org/10.1101/2020.07.24.20161851; this version posted July 27, 2020. The copyright holder for this preprint

(which was not certified by peer review) is the author/funder, who has granted medRxiv a license to display the preprint in perpetuity.

It is made available under a CC-BY-ND 4.0 International license .

and with significant beneficial properties beyond their effect on blood pressure, such as potently reducing inflammation and fibrosis and mitigating the adverse effects of metabolic syndrome. ${ }^{37-41}$ As a consequence, there is increasing interest to consider ARB treatment for a larger number of disorders beyond hypertension. There are 1,724 clinical studies presently testing the use of ARBs not only for cardiovascular disease, but for many other clinical conditions. ${ }^{42}$ For these reasons it is expected that a large and increasing number of patients will be medicated with ARBs at the time of their COVID-19 diagnosis.

Initial concerns for continued use of ARBs in COVID-19 patients have been rebutted, with the consensus now being that ARBs should not be withdrawn when prescribed for comorbidities, since they do not adversely influence COVID-19 prognosis and progression. ${ }^{37,40,43-47}$ Moreover, it is possible that treatment with ARBs might actually be beneficial, since these compounds protect lung function, reducing pneumonia-related deaths associated with hyper-inflammation. ${ }^{48-52}$ Preliminary reports now suggest that ARBs may reduce COVID-19 disease severity. ${ }^{53-55}$ A large-scale observational study of hospitalized COVID-19 patients with preexisting hypertension demonstrated a profound reduction in mortality in patients taking ARBs compared to other antihypertensive drugs. ${ }^{55}$

Nevertheless, it is most important to clearly determine whether ARBs could be beneficial to ameliorate or delay COVID-19 progress, reduce mortality and improve health during recovery, and the effects of ARBs on COVID-19 patients are under intense scrutiny. To this date (07/17/2020), there are 45 ongoing prospective clinical trials registered with clinicaltrials.gov ${ }^{42}$ to determine the precise impact of ARB use in COVID-19 patients.

Our data also demonstrate that while ARBs are frequently prescribed for patients with COVID-19 comorbidities, ARB use is not uniform within the US population. The incidence of COVID-19 is higher among individuals with lower socioeconomic status who are subject to increased exposure to SARS-CoV2 by virtue of their need to continue working in environments prone to contagion, as well as living in a crowded home environment. COVID-19 incidence is also higher in elderly, males, racial/ethnic minority (i.e., Hispanics, Blacks and Native Americans) populations, as well as those patients previously affected by hypertension, diabetes, obesity, cardiovascular and kidney disease; considered to be risk factors and co-morbidities. ${ }^{15-24}$ In this study, we found ARB use to be lowest in these sociodemographic subgroups.

For these reasons, determination of ARB benefit should be tempered by the consideration that those individuals treated with ARBs may have better overall physical health and less intense exposure to the coronavirus, confounding factors to consider when reaching final conclusions on ARB benefits. 
medRxiv preprint doi: https://doi.org/10.1101/2020.07.24.20161851; this version posted July 27, 2020. The copyright holder for this preprint (which was not certified by peer review) is the author/funder, who has granted medRxiv a license to display the preprint in perpetuity. It is made available under a CC-BY-ND 4.0 International license .

Comparison of incidence and outcomes of COVID-19 for ARB use compared with other RAS inhibitors such as ACE inhibitors, and other classes of antihypertensive drugs are under way. ${ }^{42}$

Our study has several limitations: 1) since survey participants were non-institutionalized civilians, the study results may not be extrapolated to those living in nursing homes or incarcerated individuals where COVID-19 has been prevalent and should only be generalized to the community-dwelling US adult population; 2) diagnoses of the comorbidities and medication use presented here are based on self-report and may be subject to error due to recall bias; and 3) this study does not address the use of single ARB therapy compared with the use of ARBs combined with additional antihypertensive drugs or compliance to treatment. Evaluation of the use of ARBs among the highly affected Native American population was not possible in this study.

In conclusion, our report will inform both clinical practice and research, and will be useful in prioritizing future studies on whether ARB use influences SARS-CoV-2 infection rates, the development of symptoms, the severity of the illness, the prognosis of COVID-19, and the process of recovery in the subpopulations evaluated here.

\section{References}

1. Aguila EJT, Cua IHY, Fontanilla JAC, Yabut VLM, Causing MFP. Gastrointestinal Manifestations of COVID-19: Impact on Nutrition Practices. Nutr Clin Pract. 2020.

2. Hardenberg JH, Luft FC. Covid-19, ACE2, and the kidney. Acta Physiol (Oxf). 2020:e13539.

3. Kukla M, Skonieczna-Zydecka K, Kotfis K, et al. COVID-19, MERS and SARS with Concomitant Liver Injury-Systematic Review of the Existing Literature. J Clin Med. 2020;9(5).

4. Nakra NA, Blumberg DA, Herrera-Guerra A, Lakshminrusimha S. Multi-System Inflammatory Syndrome in Children (MIS-C) Following SARS-CoV-2 Infection: Review of Clinical Presentation, Hypothetical Pathogenesis, and Proposed Management. Children (Basel). 2020;7(7).

5. Speth MM, Singer-Cornelius T, Oberle M, Gengler I, Brockmeier SJ, Sedaghat AR. Mood, anxiety and olfactory dysfunction in COVID-19: evidence of central nervous system involvement? Laryngoscope. 2020.

6. Wu L, O'Kane AM, Peng H, Bi Y, Motriuk-Smith D, Ren J. SARS-CoV-2 and cardiovascular complications: From molecular mechanisms to pharmaceutical management. Biochem Pharmacol. 2020;178:114114.

7. $\mathrm{Wu} \mathrm{Y,} \mathrm{Xu} \mathrm{X,} \mathrm{Chen} \mathrm{Z,} \mathrm{et} \mathrm{al.} \mathrm{Nervous} \mathrm{system} \mathrm{involvement} \mathrm{after} \mathrm{infection} \mathrm{with} \mathrm{COVID-19} \mathrm{and}$ other coronaviruses. Brain Behav Immun. 2020;87:18-22.

8. Fang X, Li S, Yu H, et al. Epidemiological, comorbidity factors with severity and prognosis of COVID-19: a systematic review and meta-analysis. Aging (Albany NY). 2020;12.

9. Gupta S, Hayek SS, Wang W, et al. Factors Associated With Death in Critically Ill Patients With Coronavirus Disease 2019 in the US. JAMA Intern Med. 2020.

10. Abdolahi N, Kaheh E, Golsha R, et al. Letter to the editor: efficacy of different methods of combination regimen administrations including dexamethasone, intravenous immunoglobulin, and interferon-beta to treat critically ill COVID-19 patients: a structured summary of a study protocol for a randomized controlled trial. Trials. 2020;21(1):549. 
medRxiv preprint doi: https://doi.org/10.1101/2020.07.24.20161851; this version posted July 27, 2020. The copyright holder for this preprint

(which was not certified by peer review) is the author/funder, who has granted medRxiv a license to display the preprint in perpetuity.

It is made available under a CC-BY-ND 4.0 International license .

11. Beigel JH, Tomashek KM, Dodd LE, et al. Remdesivir for the Treatment of Covid-19 Preliminary Report. The New England journal of medicine. 2020.

12. Shen C, Wang Z, Zhao F, et al. Treatment of 5 Critically Ill Patients With COVID-19 With Convalescent Plasma. JAMA. 2020.

13. Sohag AAM, Hannan MA, Rahman S, et al. Revisiting potential druggable targets against SARSCoV-2 and repurposing therapeutics under preclinical study and clinical trials: A comprehensive review. Drug Dev Res. 2020.

14. Group RC, Horby P, Lim WS, et al. Dexamethasone in Hospitalized Patients with Covid-19 Preliminary Report. The New England journal of medicine. 2020.

15. Severe Outcomes Among Patients with Coronavirus Disease 2019 (COVID-19) - United States, February 12-March 16, 2020. MMWR Morbidity and mortality weekly report. 2020;69(12):343346.

16. Bolourian A, Mojtahedi Z. Obesity and COVID-19: The mTOR pathway as a possible culprit. Obesity reviews : an official journal of the International Association for the Study of Obesity. 2020.

17. Esai Selvan M. Publisher Correction: Risk factors for death from COVID-19. Nat Rev Immunol. 2020;20(7):448.

18. Espinosa OA, Zanetti ADS, Antunes EF, Longhi FG, Matos TA, Battaglini PF. Prevalence of comorbidities in patients and mortality cases affected by SARS-CoV2: a systematic review and meta-analysis. Rev Inst Med Trop Sao Paulo. 2020;62:e43.

19. Garg S, Kim L, Whitaker M, et al. Hospitalization Rates and Characteristics of Patients Hospitalized with Laboratory-Confirmed Coronavirus Disease 2019 - COVID-NET, 14 States, March 1-30, 2020. MMWR Morbidity and mortality weekly report. 2020;69(15):458-464.

20. Kassir R. Risk of COVID-19 for patients with obesity. Obesity reviews : an official journal of the International Association for the Study of Obesity. 2020;21(6):e13034.

21. Klang E, Kassim G, Soffer S, Freeman R, Levin MA, Reich DL. Morbid Obesity as an Independent Risk Factor for COVID-19 Mortality in Hospitalized Patients Younger than 50. Obesity (Silver Spring, Md). 2020.

22. Preskorn SH. The 5\% of the Population at High Risk for Severe COVID-19 Infection Is Identifiable and Needs to Be Taken Into Account When Reopening the Economy. J Psychiatr Pract. 2020;26(3):219-227.

23. Singh AK, Gillies CL, Singh R, et al. Prevalence of comorbidities and their association with mortality in patients with COVID-19: A Systematic Review and Meta-analysis. Diabetes, obesity \& metabolism. 2020.

24. Xu L, Mao Y, Chen G. Risk factors for 2019 novel coronavirus disease (COVID-19) patients progressing to critical illness: a systematic review and meta-analysis. Aging (Albany NY). $2020 ; 12$.

25. Sfera A, Osorio C, Jafri N, Diaz EL, Campo Maldonado JE. Intoxication With Endogenous Angiotensin II: A COVID-19 Hypothesis. Front Immunol. 2020;11:1472.

26. Paul M, Poyan Mehr A, Kreutz R. Physiology of local renin-angiotensin systems. Physiol Rev. 2006;86(3):747-803.

27. Rein J, Bader M. Renin-Angiotensin System in Diabetes. Protein Pept Lett. 2017;24(9):833-840.

28. Takimoto-Ohnishi E, Murakami K. Renin-angiotensin system research: from molecules to the whole body. J Physiol Sci. 2019;69(4):581-587.

29. Black HR, Bailey J, Zappe D, Samuel R. Valsartan: more than a decade of experience. Drugs. 2009;69(17):2393-2414.

30. Bochar OM, Sklyarova HY, Faynyk AF, Bochar VT, Kuzminov YB, Bazylevych AY. The effect of therapy with olmesartan or telmisartan in patients with arterial hypertension combined with obesity. Wiad Lek. 2020;73(2):321-324.

31. Chrysant SG. Clinical experience with the use of angiotensin receptor blockers in patients with cardiovascular, cerebrovascular and renal diseases. Curr Clin Pharmacol. 2006;1(2):139-146. 
medRxiv preprint doi: https://doi.org/10.1101/2020.07.24.20161851; this version posted July 27, 2020. The copyright holder for this preprint

(which was not certified by peer review) is the author/funder, who has granted medRxiv a license to display the preprint in perpetuity.

It is made available under a CC-BY-ND 4.0 International license.

32. Schindler C, Bramlage P, Thoenes M, Bramlage C, Kirch W. Cardiovascular risk in obese hypertensive patients taking various antihypertensive drugs. Clin Drug Investig. 2007;27(10):707-717.

33. NHANES. In: (NCHS) NCfHS, ed. (CDC) CfDCaP, trans. National Health and Nutrition Examination Survey Data. Hyattville, MD: US. Department of Health and Human Services, Centers for Disease Control and Prevention.

34. Richardson S, Hirsch JS, Narasimhan M, et al. Presenting Characteristics, Comorbidities, and Outcomes Among 5700 Patients Hospitalized With COVID-19 in the New York City Area. JAMA. 2020.

35. NHANES Response Rates and Population Totals. https://wwwn.cdc.gov/nchs/nhanes/ResponseRates.aspx. Accessed 07/20/2020.

36. James PA, Oparil S, Carter BL, et al. 2014 evidence-based guideline for the management of high blood pressure in adults: report from the panel members appointed to the Eighth Joint National Committee (JNC 8). JAMA. 2014;311(5):507-520.

37. Saavedra JM. Angiotensin receptor blockers and COVID-19. Pharmacol Res. 2020a; 156:104832.

38. Sherling DH, Perumareddi P, Hennekens CH. Metabolic Syndrome. J Cardiovasc Pharmacol Ther. 2017;22(4):365-367.

39. Skurk T, Hauner H. Obesity and impaired fibrinolysis: role of adipose production of plasminogen activator inhibitor-1. Int J Obes Relat Metab Disord. 2004;28(11):1357-1364.

40. Speth RC. Keep taking your ACE inhibitors and ARBs during the COVID 19 pandemic. J Travel Med. 2020a;27(3).

41. Villapol S. Roles of Peroxisome Proliferator-Activated Receptor Gamma on Brain and Peripheral Inflammation. Cell Mol Neurobiol. 2018;38(1):121-132.

42. ClinicalTrials.gov. clinicaltrial.gov. Accessed 07/17/2020.

43. Position Statement of the ESC Council on Hypertension on ACE-Inhibitors and Angiotensin Receptor Blockers. https://www.escardio.org/Councils/Council-on-Hypertension(CHT)/News/position-statement-of-the-esc-council-on-hypertension-on-ace-inhibitors-and-ang. Accessed 07/09/2020.

44. Bozkurt B, Kovacs R, Harrington B. Joint HFSA/ACC/AHA Statement Addresses Concerns Re: Using RAAS Antagonists in COVID-19. J Card Fail. 2020;26(5):370.

45. Saavedra JM. Angiotensin receptor blockers for the treatment of COVID-19 and its comorbidities. Pharmacol Res. 2020b;159:104958.

46. Saavedra JM. COVID-19, Angiotensin Receptor Blockers, and the Brain. Cell Mol Neurobiol. 2020c;40(5):667-674.

47. Speth RC. Response to recent commentaries regarding the involvement of angiotensin-converting enzyme 2 (ACE2) and renin-angiotensin system blockers in SARS-CoV-2 infections. Drug Dev Res. 2020b.

48. Fedson DS. Treating the host response to emerging virus diseases: lessons learned from sepsis, pneumonia, influenza and Ebola. Ann Transl Med. 2016;4(21):421.

49. Gurwitz D. Angiotensin receptor blockers as tentative SARS-CoV-2 therapeutics. Drug Dev Res. 2020.

50. Jia H. Pulmonary Angiotensin-Converting Enzyme 2 (ACE2) and Inflammatory Lung Disease. Shock. 2016;46(3):239-248.

51. Schmieder RE. Mechanisms for the clinical benefits of angiotensin II receptor blockers. American journal of hypertension. 2005;18(5 Pt 1):720-730.

52. Soto M, Bang SI, McCombs J, Rodgers KE. Renin Angiotensin system-modifying therapies are associated with improved pulmonary health. Clin Diabetes Endocrinol. 2017;3:6.

53. Carey RM, Wang JG. Evidence That Renin-Angiotensin System Inhibitors Should Not Be Discontinued Due to the COVID-19 Pandemic. Hypertension. 2020;76(1):42-43.

54. Liu Y, Huang F, Xu J, et al. Anti-hypertensive Angiotensin II receptor blockers associated to mitigation of disease severity in elderly COVID-19 patients. 2020:2020.2003.2020.20039586. 
medRxiv preprint doi: https://doi.org/10.1101/2020.07.24.20161851; this version posted July 27, 2020. The copyright holder for this preprint (which was not certified by peer review) is the author/funder, who has granted medRxiv a license to display the preprint in perpetuity.

It is made available under a CC-BY-ND 4.0 International license .

55. Zhou F, Liu YM, Xie J, et al. Comparative Impacts of ACE (Angiotensin-Converting Enzyme) Inhibitors Versus Angiotensin II Receptor Blockers on the Risk of COVID-19 Mortality. Hypertension. 2020;76(2):e15-e17. 
Table 1 Prevalence of ARB use Among US Adults Overall and Those with Select Conditions ${ }^{\mathrm{a}}$

\begin{tabular}{|c|c|c|c|c|}
\hline Diagnoses $^{b}$ & $\begin{array}{c}\text { All Participants } \\
\text { No. } \\
\text { (millions) }^{\mathrm{c}}\end{array}$ & $\begin{array}{c}\text { All Participants } \\
\%^{\mathrm{c}} \\
(\mathbf{9 5 \%} \mathrm{CI}) \\
\end{array}$ & $\begin{array}{l}\text { ARB Use } \\
\text { No. } \\
\text { (millions) }^{\mathfrak{c}}\end{array}$ & $\begin{array}{l}\text { ARB Use } \\
\%^{c} \\
(95 \% \text { CI }) \\
\end{array}$ \\
\hline General Adult Population & $\begin{array}{c}39749 \\
(224.376) \\
\end{array}$ & 100 & $\begin{array}{c}2989 \\
(14.359) \\
\end{array}$ & $\begin{array}{c}6.4 \\
(6.0,6.8)\end{array}$ \\
\hline Hypertension & $\begin{array}{c}14227 \\
(70.887)\end{array}$ & $\begin{array}{c}31.6 \\
(30.7,32.6)\end{array}$ & $\begin{array}{c}2763 \\
(13.477)\end{array}$ & $\begin{array}{c}19.0 \\
(17.9,20.2)\end{array}$ \\
\hline Diabetes & $\begin{array}{c}5137 \\
(21.357) \\
\end{array}$ & $\begin{array}{c}9.7 \\
(9.3,10.2)\end{array}$ & $\begin{array}{c}1034 \\
(4.121) \\
\end{array}$ & $\begin{array}{c}19.3 \\
(17.8,20.9) \\
\end{array}$ \\
\hline Coronary Heart Disease & $\begin{array}{c}1644 \\
(7.740)\end{array}$ & $\begin{array}{c}3.5 \\
(3.2,3.8)\end{array}$ & $\begin{array}{c}331 \\
(1.431)\end{array}$ & $\begin{array}{c}18.5 \\
(15.8,21.5)\end{array}$ \\
\hline Stroke & $\begin{array}{c}1591 \\
(6.583)\end{array}$ & $\begin{array}{c}2.9 \\
(2.7,3.2)\end{array}$ & $\begin{array}{c}281 \\
(1.134)\end{array}$ & $\begin{array}{c}17.2 \\
(14.9,19.9)\end{array}$ \\
\hline Kidney Disease & $\begin{array}{c}1322 \\
(5.784)\end{array}$ & $\begin{array}{c}2.6 \\
(2.4,2.8)\end{array}$ & $\begin{array}{c}244 \\
(0.969)\end{array}$ & $\begin{array}{c}16.8 \\
(13.8,20.3)\end{array}$ \\
\hline Congestive Heart Failure & $\begin{array}{c}1355 \\
(5.458)\end{array}$ & $2.4(2.2,2.6)$ & $\begin{array}{c}258 \\
(1.001)\end{array}$ & $\begin{array}{c}18.3 \\
(15.8,21.2)\end{array}$ \\
\hline Obesity & $\begin{array}{c}14296 \\
(79.530)\end{array}$ & $\begin{array}{c}37.2 \\
(36.2,38.2)\end{array}$ & $\begin{array}{c}1528 \\
(7.554)\end{array}$ & $\begin{array}{c}9.5 \\
(8.8,10.2)\end{array}$ \\
\hline Asthma & $\begin{array}{c}5637 \\
(32.932)\end{array}$ & $\begin{array}{c}14.7 \\
(14.1,15.3)\end{array}$ & $\begin{array}{c}526 \\
(2.423)\end{array}$ & $\begin{array}{c}7.4 \\
(6.5,8.4)\end{array}$ \\
\hline $\begin{array}{l}\text { Chronic Obstructive } \\
\text { Pulmonary Disease }^{\mathrm{d}}\end{array}$ & $\begin{array}{c}679 \\
(3.680)\end{array}$ & $\begin{array}{c}3.7 \\
(3.1,4.3) \\
\end{array}$ & $\begin{array}{c}100 \\
(0.463)\end{array}$ & $\begin{array}{c}12.6 \\
(9.5,16.6)\end{array}$ \\
\hline
\end{tabular}

${ }^{a}$ All participants were aged 20 years or older in data of 7 biannual cycles (2005-2018)

${ }^{\mathrm{b}}$ Diagnoses were obtained from the health questionnaire data via participant self-report

${ }^{\mathrm{c}}$ Values of millions, $\%$, and $95 \% \mathrm{CI}$ are weighted to be nationally representative

${ }^{\mathrm{d}}$ Biannual cycles 2013-2014 thru 2017-2018 only 
Figure 1. Trends in Angiotensin Receptor Blocker Use Across NHANES Biannual Cycles 2005-2018 Among Adults and by Diabetes, Hypertension and Obesity Diagnoses

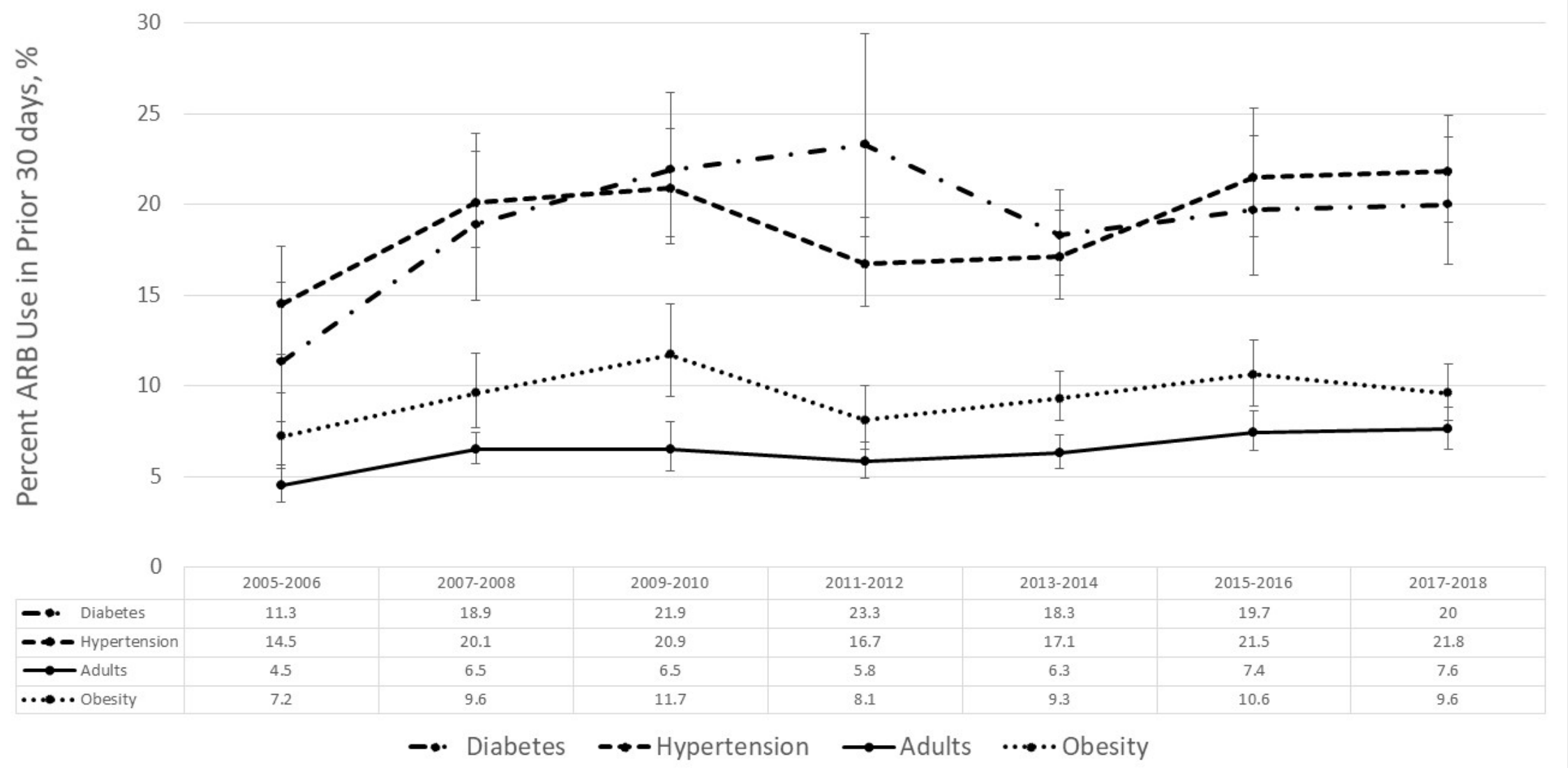

Figure 1 cont'd Number of Adult Participants Across NHANES Biannual Cycles 2005-2018 Overall and by Diabetes, Hypertension and Obesity Diagnoses

\begin{tabular}{|l|l|l|l|l|l|l|l|}
\hline & $2005-2006$ & $2007-2008$ & $2009-2010$ & $2011-2012$ & $2013-2014$ & $2015-2016$ & $2017-2018$ \\
\hline Diabetes & 4979 & 5935 & 6218 & 5560 & 5769 & 5719 & 5569 \\
\hline Hypertension & 1574 & 2124 & 2192 & 2003 & 2145 & 2070 & 2119 \\
\hline Adults & 509 & 757 & 725 & 704 & 722 & 844 & 876 \\
\hline Obesity & 1647 & 2049 & 2285 & 1873 & 2083 & 2188 & 2171 \\
\hline
\end{tabular}


All trends statistically significant except of angiotensin receptor blocker use among those with obesity ( $\mathrm{p}$ for trend $=0.12$ ). All data are weighted to be nationally representative. Errors bars indicate 95\% CIs. 
Table 2. Prevalence of Angiotensin Receptor Blocker Use in the Prior 30 days Among US Adults with Hypertension by Sociodemographic Characteristics and Body Mass Index ${ }^{\mathrm{a}}$

\begin{tabular}{|c|c|c|c|c|c|c|c|c|}
\hline \multirow{4}{*}{ Parameter } & & \multicolumn{7}{|c|}{ Hypertension } \\
\hline & & \multirow{2}{*}{\multicolumn{2}{|c|}{$\begin{array}{c}\text { Total Population } \\
(\mathrm{N}=\mathbf{1 4 , 2 2 7 ,}, \mathbf{7 0 . 8 8 7} \text { million })^{b}\end{array}$}} & \multicolumn{5}{|c|}{$\begin{array}{c}\text { ARB Use } \\
\text { (N=2763, 13.476 million) }\end{array}$} \\
\hline & & & & \multicolumn{3}{|c|}{$\begin{array}{l}\text { Prevalence of ARB Use } \\
\text { Within Subgroup }\end{array}$} & \multicolumn{2}{|c|}{$\begin{array}{l}\text { Prevalence of ARB Use } \\
\text { Across Subgroup }\end{array}$} \\
\hline & & $\begin{array}{c}\text { No. } \\
\text { (millions) }^{\mathrm{b}}\end{array}$ & $\begin{array}{c}\%^{\mathrm{b}} \\
(95 \% \mathrm{CI})\end{array}$ & $\begin{array}{c}\text { No. } \\
\text { (millions) }^{\mathrm{b}}\end{array}$ & $\begin{array}{c}\%^{\mathrm{b}} \\
(95 \% \mathrm{CI})\end{array}$ & $\begin{array}{c}\mathrm{OR}^{\mathrm{c}} \\
(95 \% \mathrm{CI})\end{array}$ & $\begin{array}{c}\%^{\mathrm{b}} \\
(95 \% \mathrm{CI})\end{array}$ & p-values ${ }^{\mathrm{e}}$ \\
\hline \multirow[t]{3}{*}{ Age } & $\leq 44$ & $\begin{array}{c}2371 \\
(14.333)\end{array}$ & $\begin{array}{c}20.2 \\
(19.1,21.4)\end{array}$ & $\begin{array}{c}175 \\
(1.114)\end{array}$ & $\begin{array}{c}7.8 \\
(6.5,9.3)\end{array}$ & $1.00^{\mathrm{d}}$ & $\begin{array}{c}8.3 \\
(6.9,9.9)\end{array}$ & \multirow[t]{3}{*}{$<0.001$} \\
\hline & $45-64$ & $\begin{array}{c}5724 \\
(31.345)\end{array}$ & $\begin{array}{c}44.2 \\
(43.1,45.3)\end{array}$ & $\begin{array}{c}1048 \\
(5.786)\end{array}$ & $\begin{array}{c}18.5 \\
(17.0,20.0)\end{array}$ & $\begin{array}{c}2.68 \\
(2.20,3.28)\end{array}$ & $\begin{array}{c}42.9 \\
(40.1,45.8)\end{array}$ & \\
\hline & $\geq 65$ & $\begin{array}{c}6132 \\
(25.210)\end{array}$ & $\begin{array}{c}35.6 \\
(34.3,36.9)\end{array}$ & $\begin{array}{l}1540 \\
(6.576)\end{array}$ & $\begin{array}{c}26.1 \\
(24.3,28.0)\end{array}$ & $\begin{array}{c}4.19 \\
(3.41,5.14)\end{array}$ & $\begin{array}{c}48.8 \\
(45.8,51.8)\end{array}$ & \\
\hline \multirow[t]{2}{*}{ Gender } & Male & $\begin{array}{c}6819 \\
(33.814) \\
\end{array}$ & $\begin{array}{c}47.7 \\
(46.7,48.7) \\
\end{array}$ & $\begin{array}{c}1159 \\
(5.470) \\
\end{array}$ & $\begin{array}{c}16.2 \\
(15.0,17.4) \\
\end{array}$ & 1.0 & $\begin{array}{c}40.6 \\
(38.2,43.0) \\
\end{array}$ & \multirow[t]{2}{*}{$<0.001$} \\
\hline & Female & $\begin{array}{c}7408 \\
(37.073)\end{array}$ & $\begin{array}{c}52.3 \\
(51.3,53.3)\end{array}$ & $\begin{array}{c}1604 \\
(8.006)\end{array}$ & $\begin{array}{c}21.6 \\
(20.1,23.2)\end{array}$ & $\begin{array}{c}1.43 \\
(1.30,1.59)\end{array}$ & $\begin{array}{c}59.4 \\
(57.0,61.8)\end{array}$ & \\
\hline \multirow{4}{*}{$\begin{array}{l}\text { Race/ } \\
\text { Ethnicity }\end{array}$} & Non-Hispanic white & $\begin{array}{c}6139 \\
(48.955)\end{array}$ & $\begin{array}{c}69.1 \\
(66.3,71.7)\end{array}$ & $\begin{array}{c}1173 \\
(9.612)\end{array}$ & $\begin{array}{c}19.6 \\
(18.2,21.2)\end{array}$ & 1.0 & $\begin{array}{c}71.3 \\
(67.9,74.5)\end{array}$ & \multirow[t]{4}{*}{0.001} \\
\hline & Hispanic & $\begin{array}{c}2906 \\
(7.001) \\
\end{array}$ & $\begin{array}{c}9.9 \\
(8.5,11.5) \\
\end{array}$ & $\begin{array}{c}507 \\
(1.032) \\
\end{array}$ & $\begin{array}{c}14.7 \\
(13.1,16.5) \\
\end{array}$ & $\begin{array}{c}0.71 \\
(0.60,0.83) \\
\end{array}$ & $\begin{array}{c}7.7 \\
(6.1,9.6) \\
\end{array}$ & \\
\hline & Non-Hispanic black & $\begin{array}{c}3913 \\
(10.188)\end{array}$ & $\begin{array}{c}14.4 \\
(12.6,16.3)\end{array}$ & $\begin{array}{c}774 \\
(1.922)\end{array}$ & $\begin{array}{c}18.9 \\
(17.4,20.5)\end{array}$ & $\begin{array}{c}0.95 \\
(0.83,1.09)\end{array}$ & $\begin{array}{c}14.3 \\
(12.1,16.7)\end{array}$ & \\
\hline & Other race & $\begin{array}{c}1269 \\
(4.743) \\
\end{array}$ & $\begin{array}{c}6.7 \\
(5.9,7.6) \\
\end{array}$ & $\begin{array}{c}309 \\
(0.910)\end{array}$ & $\begin{array}{c}19.2 \\
(16.6,22.0)\end{array}$ & $\begin{array}{c}0.97 \\
(0.80,1.18) \\
\end{array}$ & $\begin{array}{c}6.8 \\
(5.7,8.0) \\
\end{array}$ & \\
\hline \multirow[t]{2}{*}{ Household Income } & $\geq \$ 20 \mathrm{k}$ & $\begin{array}{c}9842 \\
(55.763) \\
\end{array}$ & $\begin{array}{c}82.2 \\
(80.9,83.5)\end{array}$ & $\begin{array}{c}2005 \\
(11.058)\end{array}$ & $\begin{array}{c}19.8 \\
(18.5,21.2)\end{array}$ & $\begin{array}{c}1.39 \\
(1.20,1.61)\end{array}$ & $\begin{array}{c}85.9 \\
(83.9,87.6)\end{array}$ & \multirow[t]{2}{*}{$<0.001$} \\
\hline & $<\$ 20 \mathrm{k}$ & $\begin{array}{c}3580 \\
(12.047) \\
\end{array}$ & $\begin{array}{c}17.8 \\
(16.5,19.1) \\
\end{array}$ & $\begin{array}{c}597 \\
(1.822) \\
\end{array}$ & $\begin{array}{c}15.1 \\
(13.6,16.8)\end{array}$ & 1.0 & $\begin{array}{c}14.1 \\
(12.4,16.1) \\
\end{array}$ & \\
\hline \multirow[t]{2}{*}{ Education } & Some college or higher & $\begin{array}{c}6702 \\
(39.553)\end{array}$ & $\begin{array}{c}55.9 \\
(54.1,57.6)\end{array}$ & $\begin{array}{c}1386 \\
(7.999)\end{array}$ & $\begin{array}{c}20.2 \\
(18.8,21.8)\end{array}$ & $\begin{array}{c}1.19 \\
(1.06,1.34)\end{array}$ & $\begin{array}{c}59.4 \\
(56.3,62.3) \\
\end{array}$ & \multirow[t]{2}{*}{0.004} \\
\hline & High School or lower & $\begin{array}{c}7495 \\
(31.234)\end{array}$ & $\begin{array}{c}44.1 \\
(42.4,45.9\end{array}$ & $\begin{array}{c}1373 \\
(5.471)\end{array}$ & $\begin{array}{c}17.5 \\
(16.2,18.9)\end{array}$ & 1.0 & $\begin{array}{c}40.6 \\
(37.7,43.7)\end{array}$ & \\
\hline \multirow[t]{2}{*}{ Health Insurance Coverage } & Yes & $\begin{array}{c}12386 \\
(63.052) \\
\end{array}$ & $\begin{array}{c}89.1 \\
(88.0,90.1) \\
\end{array}$ & $\begin{array}{c}2595 \\
(12.797) \\
\end{array}$ & $\begin{array}{c}20.3 \\
(19.1,21.6) \\
\end{array}$ & $\begin{array}{c}2.71 \\
(2.12,3.47) \\
\end{array}$ & $\begin{array}{c}95.1 \\
(93.8,96.1) \\
\end{array}$ & \multirow[t]{2}{*}{$<0.001$} \\
\hline & No & $\begin{array}{c}1819 \\
(7.716)\end{array}$ & $\begin{array}{c}10.9 \\
(9.9,12.0) \\
\end{array}$ & $\begin{array}{c}165 \\
(0.662) \\
\end{array}$ & $\begin{array}{c}8.6 \\
(7.0,10.5)\end{array}$ & 1.0 & $\begin{array}{c}4.9 \\
(3.9,6.2)\end{array}$ & \\
\hline \multirow[t]{2}{*}{$\begin{array}{l}\text { Prescription } \\
\text { Insurance Coverage }^{f}\end{array}$} & Yes & $\begin{array}{c}11394 \\
(58.861) \\
\end{array}$ & $\begin{array}{c}94.4 \\
(93.2,95.4) \\
\end{array}$ & $\begin{array}{c}2411 \\
(12.104) \\
\end{array}$ & $\begin{array}{c}20.6 \\
(19.3,21.9) \\
\end{array}$ & $\begin{array}{c}1.22 \\
(0.98,1.51) \\
\end{array}$ & $\begin{array}{c}93.5 \\
(92.7,94.1) \\
\end{array}$ & \multirow[t]{2}{*}{0.08} \\
\hline & No & $\begin{array}{c}968 \\
(4.111) \\
\end{array}$ & $\begin{array}{c}5.6 \\
(4.6,6.8) \\
\end{array}$ & $\begin{array}{c}188 \\
(0.722) \\
\end{array}$ & $\begin{array}{c}17.6 \\
(14.8,20.7)\end{array}$ & 1.0 & $\begin{array}{c}6.5 \\
(5.9,7.3)\end{array}$ & \\
\hline
\end{tabular}




\begin{tabular}{|c|c|c|c|c|c|c|c|c|}
\hline \multirow[t]{4}{*}{ Body Mass Index } & $\leq 24.99 \mathrm{~kg} / \mathrm{m}^{2}$ & $\begin{array}{c}2453 \\
(11.552)\end{array}$ & $\begin{array}{c}17.2 \\
(16.3,18.0)\end{array}$ & $\begin{array}{c}363 \\
(1.596)\end{array}$ & $\begin{array}{c}13.8 \\
(11.9,16.0)\end{array}$ & 1.0 & $\begin{array}{c}12.5 \\
(10.9,14.3)\end{array}$ & \multirow[t]{4}{*}{$<0.001$} \\
\hline & $25.00-29.99 \mathrm{~kg} / \mathrm{m}^{2}$ & $\begin{array}{c}4254 \\
(21.373)\end{array}$ & $\begin{array}{c}31.7 \\
(30.7,32.8)\end{array}$ & $\begin{array}{c}816 \\
(3.965)\end{array}$ & $\begin{array}{c}18.5 \\
(16.7,20.6)\end{array}$ & $\begin{array}{c}1.42 \\
(1.16,1.73)\end{array}$ & $\begin{array}{c}31.0 \\
(28.3,34.0)\end{array}$ & \\
\hline & $30.00-39.99 \mathrm{~kg} / \mathrm{m}^{2}$ & $\begin{array}{c}5205 \\
(26.675) \\
\end{array}$ & $\begin{array}{c}39.7 \\
(38.6,40.9)\end{array}$ & $\begin{array}{c}1108 \\
(5.573)\end{array}$ & $\begin{array}{c}20.8 \\
(19.1,22.6)\end{array}$ & $\begin{array}{c}1.64 \\
(1.37,1.96)\end{array}$ & $\begin{array}{c}43.6 \\
(40.8,46.5)\end{array}$ & \\
\hline & $\geq 40.00 \mathrm{~kg} / \mathrm{m}^{2}$ & $\begin{array}{c}1479 \\
(7.657) \\
\end{array}$ & $\begin{array}{c}11.4 \\
(10.6,12.2)\end{array}$ & $\begin{array}{c}332 \\
(1.641)\end{array}$ & $\begin{array}{c}21.4 \\
(18.5,24.7)\end{array}$ & $\begin{array}{c}1.70 \\
(1.35,2.15)\end{array}$ & $\begin{array}{c}12.8 \\
(11.0,14.9)\end{array}$ & \\
\hline
\end{tabular}

Abbreviations: OR; Odds ratio

${ }^{a}$ Diagnosis was obtained from the health questionnaire data via participant self-report in data of 7 biannual cycles (2005-2018)

${ }^{\mathrm{b}}$ Values of millions and percent $(95 \% \mathrm{CI})$ are weighted to be nationally representative

${ }^{\mathrm{c}}$ Indicates the odds of being on an angiotensin receptor blocker compared to the reference category

${ }^{\mathrm{d}}$ Indicates reference category

e Significance for the association of angiotensin receptor blocker use and the parameter

${ }^{\mathrm{f}}$ Survey question answered by those saying "yes" to having health insurance coverage 
Table 3. Prevalence of Angiotensin Receptor Blocker Use in the Prior 30 days Among US Adults with Diabetes by Social Determinants of Health and Body Mass Index ${ }^{\mathrm{a}}$

\begin{tabular}{|c|c|c|c|c|c|c|c|c|}
\hline \multirow[b]{4}{*}{ Parameter } & & \multicolumn{7}{|c|}{ Diabetes } \\
\hline & & \multirow{2}{*}{\multicolumn{2}{|c|}{$\begin{array}{c}\text { Total Population } \\
(\mathbf{N}=\mathbf{5 , 1 3 7 , 2 1 . 3 5 7} \text { million })\end{array}$}} & \multicolumn{5}{|c|}{ ARB Use ( $\mathrm{N}=1034,4.120$ million) } \\
\hline & & & & \multicolumn{3}{|c|}{$\begin{array}{l}\text { Prevalence of ARB Use } \\
\text { Within Subgroup }\end{array}$} & \multicolumn{2}{|c|}{$\begin{array}{l}\text { Prevalence of ARB Use } \\
\text { Across Subgroup }\end{array}$} \\
\hline & & $\begin{array}{c}\text { No. } \\
\text { (millions) }^{\mathrm{b}}\end{array}$ & $\begin{array}{c}\%^{\mathrm{b}} \\
(95 \% \mathrm{CI})\end{array}$ & $\begin{array}{c}\text { No. } \\
\text { (millions) }^{\mathrm{b}}\end{array}$ & $\begin{array}{c}\%{ }^{\mathrm{b}} \\
(95 \% \mathrm{CI})\end{array}$ & $\begin{array}{c}\mathrm{OR}^{\mathrm{c}} \\
(95 \% \mathrm{CI})\end{array}$ & $\begin{array}{c}\%^{\mathrm{b}} \\
(95 \% \mathrm{CI})\end{array}$ & p-value \\
\hline \multirow[t]{3}{*}{ Age } & $<=44$ & $\begin{array}{c}545 \\
(2.877)\end{array}$ & $\begin{array}{c}13.5 \\
(12.3,14.7)\end{array}$ & $\begin{array}{c}37 \\
(0.214)\end{array}$ & $\begin{array}{c}7.5 \\
(4.9,11.2)\end{array}$ & $1.0^{\mathrm{d}}$ & $\begin{array}{c}5.2 \\
(3.4,7.9)\end{array}$ & \multirow[t]{3}{*}{$<0.001$} \\
\hline & $45-64$ & $\begin{array}{c}2201 \\
(9.803) \\
\end{array}$ & $\begin{array}{c}45.9 \\
(44.1,47.8) \\
\end{array}$ & $\begin{array}{c}390 \\
(1.641) \\
\end{array}$ & $\begin{array}{c}16.7 \\
(14.6,19.1)\end{array}$ & $\begin{array}{c}2.50 \\
(1.54,4.05) \\
\end{array}$ & $\begin{array}{c}39.8 \\
(35.6,44.2) \\
\end{array}$ & \\
\hline & $>=65$ & $\begin{array}{c}2391 \\
(8.677) \\
\end{array}$ & $\begin{array}{c}40.6 \\
(38.7,42.6) \\
\end{array}$ & $\begin{array}{c}607 \\
(2.265) \\
\end{array}$ & $\begin{array}{c}26.1 \\
(23.5,28.9)\end{array}$ & $\begin{array}{c}4.38 \\
(2.69,7.13) \\
\end{array}$ & $\begin{array}{c}55.0 \\
(50.6,59.2) \\
\end{array}$ & \\
\hline \multirow[t]{2}{*}{ Gender } & Male & $\begin{array}{c}2622 \\
(10.755)\end{array}$ & $\begin{array}{c}50.4 \\
(48.2,52.5)\end{array}$ & $\begin{array}{c}477 \\
(1.880)\end{array}$ & $\begin{array}{c}17.5 \\
(15.4,19.8)\end{array}$ & 1.0 & $\begin{array}{c}45.6 \\
(41.3,50.1)\end{array}$ & \multirow[t]{2}{*}{0.03} \\
\hline & Female & $\begin{array}{c}2515 \\
(10.602)\end{array}$ & $\begin{array}{c}49.6 \\
(47.5,51.8)\end{array}$ & $\begin{array}{c}557 \\
(2.240)\end{array}$ & $\begin{array}{c}21.1 \\
(19.0,23.4)\end{array}$ & $\begin{array}{c}1.26 \\
(1.02,1.56) \\
\end{array}$ & $\begin{array}{c}54.4 \\
(49.9,58.7) \\
\end{array}$ & \\
\hline \multirow{4}{*}{$\begin{array}{l}\text { Race/ } \\
\text { Ethnicity }\end{array}$} & Non-Hispanic white & $\begin{array}{c}1758 \\
(12.948)\end{array}$ & $\begin{array}{c}60.6 \\
(57.3,63.8)\end{array}$ & $\begin{array}{c}334 \\
(2.502)\end{array}$ & $\begin{array}{c}19.3 \\
(17.1,21.8)\end{array}$ & 1.0 & $\begin{array}{c}60.7 \\
(55.6,65.6)\end{array}$ & \multirow[t]{4}{*}{$<0.001$} \\
\hline & Hispanic & $\begin{array}{c}1428 \\
(3.163)\end{array}$ & $\begin{array}{c}14.8 \\
(12.6,17.3)\end{array}$ & $\begin{array}{c}229 \\
(0.448)\end{array}$ & $\begin{array}{c}14.2 \\
(12.5,16.0)\end{array}$ & $\begin{array}{c}0.69 \\
(0.56,0.85)\end{array}$ & $\begin{array}{c}10.9 \\
(8.6,13.8)\end{array}$ & \\
\hline & Non-Hispanic black & $\begin{array}{c}1411 \\
(3.362) \\
\end{array}$ & $\begin{array}{c}15.7 \\
(13.7,18.0) \\
\end{array}$ & $\begin{array}{c}325 \\
(0.744)\end{array}$ & $\begin{array}{c}22.1 \\
(19.6,24.9) \\
\end{array}$ & $\begin{array}{c}1.19 \\
(0.96,1.46) \\
\end{array}$ & $\begin{array}{c}18.1 \\
(14.9,21.7)\end{array}$ & \\
\hline & Other race & $\begin{array}{c}540 \\
(1.884)\end{array}$ & $\begin{array}{c}8.8 \\
(7.6,10.2)\end{array}$ & $\begin{array}{c}146 \\
(0.425)\end{array}$ & $\begin{array}{c}22.6 \\
(19.1,26.5)\end{array}$ & $\begin{array}{c}1.22 \\
(0.92,1.62)\end{array}$ & $\begin{array}{c}10.3 \\
(8.4,12.7)\end{array}$ & \\
\hline \multirow[t]{2}{*}{ Household Income } & $\geq \$ 20 \mathrm{k}$ & $\begin{array}{c}3422 \\
(16.151)\end{array}$ & $\begin{array}{c}79.7 \\
(78.0,81.3)\end{array}$ & $\begin{array}{c}717 \\
(3.232)\end{array}$ & $\begin{array}{c}20.0 \\
(18.2,21.9)\end{array}$ & $\begin{array}{c}1.31 \\
(1.06,1.62)\end{array}$ & $\begin{array}{c}83.0 \\
(80.0,85.6)\end{array}$ & \multirow[t]{2}{*}{0.01} \\
\hline & $<\$ 20 \mathrm{k}$ & $\begin{array}{c}1375 \\
(4.123)\end{array}$ & $\begin{array}{c}20.3 \\
(18.7,22.0)\end{array}$ & $\begin{array}{c}248 \\
(0.662)\end{array}$ & $\begin{array}{c}16.1 \\
(13.6,18.8)\end{array}$ & 1.0 & $\begin{array}{c}17.0 \\
(14.4,20.0)\end{array}$ & \\
\hline \multirow[t]{2}{*}{ Education } & Some college or higher & $\begin{array}{c}2121 \\
(10.759) \\
\end{array}$ & $\begin{array}{c}50.4 \\
(48.1,52.8) \\
\end{array}$ & $\begin{array}{c}485 \\
(2.259) \\
\end{array}$ & $\begin{array}{c}21.0 \\
(18.5,23.7) \\
\end{array}$ & $\begin{array}{c}1.24 \\
(1.01,1.54) \\
\end{array}$ & $\begin{array}{c}54.8 \\
(50.3,59.3) \\
\end{array}$ & \multirow[t]{2}{*}{0.04} \\
\hline & High School or lower & $\begin{array}{c}3004 \\
(10.574) \\
\end{array}$ & $\begin{array}{c}49.6 \\
(47.2,51.9) \\
\end{array}$ & $\begin{array}{c}548 \\
(1.860) \\
\end{array}$ & $\begin{array}{c}17.6 \\
(15.8,19.5) \\
\end{array}$ & 1.0 & $\begin{array}{c}45.2 \\
(40.7,49.7)\end{array}$ & \\
\hline \multirow[t]{2}{*}{ Health Insurance Coverage } & Yes & $\begin{array}{c}4500 \\
(19.240)\end{array}$ & $\begin{array}{c}90.1 \\
(88.9,91.2)\end{array}$ & $\begin{array}{c}979 \\
(3.957)\end{array}$ & $\begin{array}{c}20.6 \\
(19.0,22.3)\end{array}$ & $\begin{array}{c}3.10 \\
(1.96,4.89)\end{array}$ & $\begin{array}{c}96.0 \\
(93.9,97.5)\end{array}$ & \multirow[t]{2}{*}{$<0.001$} \\
\hline & No & $\begin{array}{c}635 \\
(2.113) \\
\end{array}$ & $\begin{array}{c}9.9 \\
(8.8,11.1) \\
\end{array}$ & $\begin{array}{c}55 \\
(0.163) \\
\end{array}$ & $\begin{array}{c}7.7 \\
(5.1,11.6) \\
\end{array}$ & 1.0 & $\begin{array}{c}4.0 \\
(2.5,6.1)\end{array}$ & \\
\hline \multirow[t]{2}{*}{$\begin{array}{l}\text { Prescription } \\
\text { Insurance Coverage }^{f}\end{array}$} & Yes & $\begin{array}{c}4139 \\
(17.890) \\
\end{array}$ & $\begin{array}{c}93.1 \\
(91.8,94.2)\end{array}$ & $\begin{array}{c}912 \\
(3.740) \\
\end{array}$ & $\begin{array}{c}20.9 \\
(19.2,22.7)\end{array}$ & $\begin{array}{c}1.28 \\
(0.91,1.81) \\
\end{array}$ & $\begin{array}{c}94.3 \\
(92.2,95.8)\end{array}$ & \multirow[t]{2}{*}{0.16} \\
\hline & No & $\begin{array}{c}352 \\
(1.329) \\
\end{array}$ & $\begin{array}{c}6.9 \\
(5.8,8.2) \\
\end{array}$ & $\begin{array}{c}68 \\
(0.227) \\
\end{array}$ & $\begin{array}{c}17.1 \\
(12.8,22.5)\end{array}$ & 1.0 & $\begin{array}{c}5.7 \\
(4.2,7.8) \\
\end{array}$ & \\
\hline Body Mass Index & $\leq 24.99 \mathrm{~kg} / \mathrm{m}^{2}$ & 648 & 11.5 & 93 & 12.3 & 1.0 & 7.3 & \\
\hline
\end{tabular}




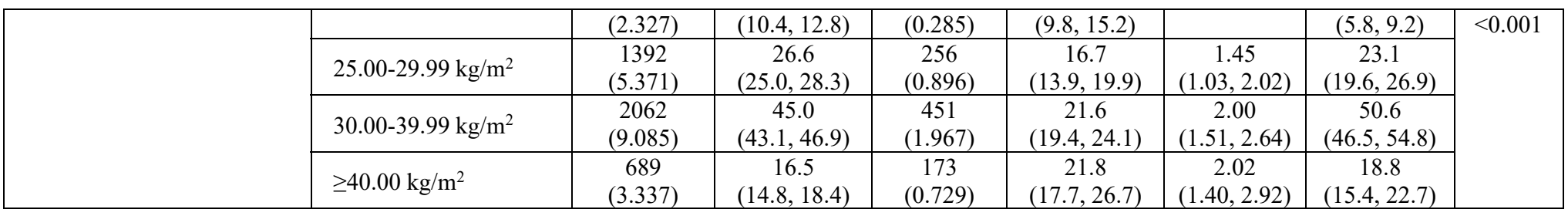

Abbreviations: OR; Odds ratio

${ }^{a}$ Diagnosis was obtained from the health questionnaire data via participant self-report in data of 7 biannual cycles (2005-2018)

${ }^{\mathrm{b}}$ Values of millions and percent $(95 \% \mathrm{CI})$ are weighted to be nationally representative

${ }^{\mathrm{c}}$ Indicates the odds of being on an angiotensin receptor blocker compared to the reference category

${ }^{\mathrm{d}}$ Indicates reference category

e Significance for the association of angiotensin receptor blocker use and the parameter

${ }^{\mathrm{f}}$ Survey question answered by those saying "yes" to having health insurance coverage 
Table 4. Prevalence of Angiotensin Receptor Blocker Use in the Prior 30 days Among US Adults with Obesity by Social Determinants of Health and Body Mass Index ${ }^{a}$

\begin{tabular}{|c|c|c|c|c|c|c|c|c|}
\hline \multirow[b]{4}{*}{ Parameter } & & \multicolumn{7}{|c|}{ Obesity $^{\text {a }}$} \\
\hline & & \multirow{2}{*}{\multicolumn{2}{|c|}{$\begin{array}{c}\text { Total Population } \\
\mathrm{N}=\mathbf{1 4 , 2 9 6 , 7 9 . 5 3 0} \text { million) }\end{array}$}} & \multicolumn{5}{|c|}{ ARB Use ( $\mathrm{N}=1528,7.554$ million) } \\
\hline & & & & \multicolumn{3}{|c|}{$\begin{array}{l}\text { Prevalence of ARB Use } \\
\text { Within Subgroup }\end{array}$} & \multicolumn{2}{|c|}{$\begin{array}{c}\text { Prevalence of ARB Use } \\
\text { Across Subgroup }\end{array}$} \\
\hline & & $\begin{array}{c}\text { No. } \\
\text { (millions) }^{\mathrm{b}}\end{array}$ & $\begin{array}{c}\%^{\mathrm{b}} \\
(95 \% \mathrm{CI})\end{array}$ & $\begin{array}{c}\text { No. } \\
\text { (millions) }^{\mathrm{b}}\end{array}$ & $(95 \% \mathrm{CI})$ & $\begin{array}{c}\text { OR }^{\mathrm{c}} \\
(95 \% \mathrm{CI})\end{array}$ & $\begin{array}{c}\%^{\mathrm{b}} \\
(95 \% \mathrm{CI})\end{array}$ & p-value ${ }^{e}$ \\
\hline \multirow[t]{3}{*}{ Age } & $<=44$ & $\begin{array}{c}5745 \\
(34.274) \\
\end{array}$ & $\begin{array}{c}43.1 \\
(41.7,44.5) \\
\end{array}$ & $\begin{array}{c}124 \\
(0.764) \\
\end{array}$ & $\begin{array}{c}2.2 \\
(1.8,2.8) \\
\end{array}$ & 1.0 & $\begin{array}{c}10.1 \\
(8.2,12.4)\end{array}$ & \multirow[t]{3}{*}{$<0.001$} \\
\hline & $45-64$ & $\begin{array}{c}5370 \\
(31.388)\end{array}$ & $\begin{array}{c}39.5 \\
(38.3,40.7) \\
\end{array}$ & $\begin{array}{c}663 \\
(3.596) \\
\end{array}$ & $\begin{array}{c}11.5 \\
(10.2,12.9) \\
\end{array}$ & $\begin{array}{c}5.68 \\
(4.48,7.20) \\
\end{array}$ & $\begin{array}{c}47.6 \\
(44.0,51.3) \\
\end{array}$ & \\
\hline & $>=65$ & $\begin{array}{c}3181 \\
(13.869)\end{array}$ & $\begin{array}{c}17.4 \\
(16.4,18.5) \\
\end{array}$ & $\begin{array}{c}741 \\
(3.193) \\
\end{array}$ & $\begin{array}{c}23.0 \\
(21.1,25.0) \\
\end{array}$ & $\begin{array}{c}13.13 \\
(10.32,16.70) \\
\end{array}$ & $\begin{array}{c}42.3 \\
(38.4,46.2) \\
\end{array}$ & \\
\hline \multirow[t]{2}{*}{ Gender } & Male & $\begin{array}{c}6260 \\
(36.801)\end{array}$ & $\begin{array}{c}46.3 \\
(45.1,47.5)\end{array}$ & $\begin{array}{c}610 \\
(3.162)\end{array}$ & $\begin{array}{c}8.6 \\
(7.7,9.5)\end{array}$ & 1.0 & $\begin{array}{c}41.9 \\
(38.5,45.3)\end{array}$ & \multirow[t]{2}{*}{0.01} \\
\hline & Female & $\begin{array}{c}8036 \\
(42.729) \\
\end{array}$ & $\begin{array}{c}53.7 \\
(52.5,54.9) \\
\end{array}$ & $\begin{array}{c}918 \\
(4.392) \\
\end{array}$ & $\begin{array}{c}10.3 \\
(9.3,11.3)\end{array}$ & $\begin{array}{c}1.22 \\
(1.05,1.41)\end{array}$ & $\begin{array}{c}58.1 \\
(54.7,61.5) \\
\end{array}$ & \\
\hline \multirow{4}{*}{$\begin{array}{l}\text { Race/ } \\
\text { Ethnicity }\end{array}$} & Non-Hispanic white & $\begin{array}{c}5639 \\
(51.547) \\
\end{array}$ & $\begin{array}{c}64.8 \\
(61.8,67.8) \\
\end{array}$ & $\begin{array}{c}626 \\
(5.317) \\
\end{array}$ & $\begin{array}{c}10.3 \\
(9.3,11.4)\end{array}$ & 1.0 & $\begin{array}{c}70.4 \\
(66.3,74.2) \\
\end{array}$ & \multirow[t]{4}{*}{$<0.001$} \\
\hline & Hispanic & $\begin{array}{c}3952 \\
(12.399)\end{array}$ & $\begin{array}{c}15.6 \\
(13.6,17.8)\end{array}$ & $\begin{array}{c}307 \\
(0.626) \\
\end{array}$ & $\begin{array}{c}5.0 \\
(4.3,5.9)\end{array}$ & $\begin{array}{c}0.46 \\
(0.38,0.56) \\
\end{array}$ & $\begin{array}{c}8.3 \\
(6.4,10.6) \\
\end{array}$ & \\
\hline & Non-Hispanic black & $\begin{array}{c}3840 \\
(11.581) \\
\end{array}$ & $\begin{array}{c}14.6 \\
(12.8,16.6) \\
\end{array}$ & $\begin{array}{c}503 \\
(1.297) \\
\end{array}$ & $\begin{array}{c}11.2 \\
(10.1,12.4) \\
\end{array}$ & $\begin{array}{c}1.10 \\
(0.94,1.28)\end{array}$ & $\begin{array}{c}17.2 \\
(14.4,20.4)\end{array}$ & \\
\hline & Other race & $\begin{array}{c}865 \\
(4.003) \\
\end{array}$ & $\begin{array}{c}5.0 \\
(4.5,5.7)\end{array}$ & $\begin{array}{c}92 \\
(0.314) \\
\end{array}$ & $\begin{array}{c}7.8 \\
(6.3,9.7)\end{array}$ & $\begin{array}{c}0.74 \\
(0.58,0.93)\end{array}$ & $\begin{array}{c}4.2 \\
(3.3,5.2)\end{array}$ & \\
\hline \multirow[t]{2}{*}{ Household Income } & $\geq \$ 20 \mathrm{k}$ & $\begin{array}{c}10513 \\
(65.069) \\
\end{array}$ & $\begin{array}{c}85.0 \\
(83.9,86.1) \\
\end{array}$ & $\begin{array}{c}1088 \\
(6.143) \\
\end{array}$ & $\begin{array}{c}9.4 \\
(8.6,10.3) \\
\end{array}$ & $\begin{array}{c}0.99 \\
(0.83,1.19) \\
\end{array}$ & $\begin{array}{c}85.0 \\
(82.3,87.3) \\
\end{array}$ & \multirow[t]{2}{*}{0.96} \\
\hline & $<\$ 20 \mathrm{k}$ & $\begin{array}{c}3078 \\
(11.446) \\
\end{array}$ & $\begin{array}{c}15.0 \\
(13.9,16.1) \\
\end{array}$ & $\begin{array}{c}355 \\
(1.085) \\
\end{array}$ & $\begin{array}{c}9.5 \\
(8.3,10.8) \\
\end{array}$ & 1.0 & $\begin{array}{c}15.0 \\
(12.7,17.7)\end{array}$ & \\
\hline \multirow[t]{2}{*}{ Education } & Some college or higher & $\begin{array}{c}7114 \\
(45.987) \\
\end{array}$ & $\begin{array}{c}57.9 \\
(56.4,59.3) \\
\end{array}$ & $\begin{array}{c}770 \\
(4.514) \\
\end{array}$ & $\begin{array}{c}9.8 \\
(8.9,10.8) \\
\end{array}$ & $\begin{array}{c}1.09 \\
(0.95,1.25) \\
\end{array}$ & $\begin{array}{c}59.8 \\
(56.4,63.1) \\
\end{array}$ & \multirow[t]{2}{*}{0.21} \\
\hline & High School or lower & $\begin{array}{c}7167 \\
(33.488) \\
\end{array}$ & $\begin{array}{c}42.1 \\
(40.7,43.6) \\
\end{array}$ & $\begin{array}{c}756 \\
(3.038) \\
\end{array}$ & $\begin{array}{c}9.1 \\
(8.2,10.0) \\
\end{array}$ & 1.0 & $\begin{array}{c}40.2 \\
(36.9,43.6) \\
\end{array}$ & \\
\hline \multirow[t]{2}{*}{ Health Insurance Coverage } & Yes & $\begin{array}{c}11394 \\
(66.306) \\
\end{array}$ & $\begin{array}{c}83.5 \\
(82.2,84.7) \\
\end{array}$ & $\begin{array}{c}1436 \\
(7.119) \\
\end{array}$ & $\begin{array}{c}10.7 \\
(9.9,11.6)\end{array}$ & $\begin{array}{c}3.57 \\
(2.55,5.01)\end{array}$ & $\begin{array}{c}94.3 \\
(92.3,95.9) \\
\end{array}$ & \multirow[t]{2}{*}{$<0.001$} \\
\hline & No & $\begin{array}{c}2888 \\
(13.127) \\
\end{array}$ & $\begin{array}{c}16.5 \\
(15.3,17.8) \\
\end{array}$ & $\begin{array}{c}91 \\
(0.427) \\
\end{array}$ & $\begin{array}{c}3.3 \\
(2.4,4.4)\end{array}$ & 1.0 & $\begin{array}{c}5.7 \\
(4.1,7.7) \\
\end{array}$ & \\
\hline \multirow[t]{2}{*}{$\begin{array}{l}\text { Prescription } \\
\text { Insurance Coverage }^{f}\end{array}$} & Yes & $\begin{array}{c}10600 \\
(62.365) \\
\end{array}$ & $\begin{array}{c}94.6 \\
(93.9,95.1) \\
\end{array}$ & $\begin{array}{c}1357 \\
(6.802) \\
\end{array}$ & $\begin{array}{c}10.9 \\
(10.0,11.9) \\
\end{array}$ & $\begin{array}{c}1.12 \\
(0.82,1.53)\end{array}$ & $\begin{array}{c}95.1 \\
(93.5,96.3) \\
\end{array}$ & \multirow[t]{2}{*}{0.46} \\
\hline & No & $\begin{array}{c}726 \\
(3.589)\end{array}$ & $\begin{array}{c}5.4 \\
(4.9,6.1)\end{array}$ & $\begin{array}{c}86 \\
(0.352)\end{array}$ & $\begin{array}{c}9.8 \\
(7.4,12.9)\end{array}$ & 1.0 & $\begin{array}{c}4.9 \\
(3.7,6.5)\end{array}$ & \\
\hline
\end{tabular}

Abbreviations: OR; Odds ratio 
${ }^{a}$ Obesity was defined as body mass index of $\geq 30 \mathrm{~kg} / \mathrm{m}^{2}$ in data of 7 biannual cycles (2005-2018)

${ }^{\mathrm{b}}$ Values of millions and percent $(95 \% \mathrm{CI})$ are weighted to be nationally representative

${ }^{\mathrm{c}}$ Indicates the odds of being on an angiotensin receptor blocker compared to the reference category

${ }^{\mathrm{d}}$ Indicates reference category

${ }^{\mathrm{e}}$ Significance for the association of angiotensin receptor blocker use and the parameter

${ }^{\text {f }}$ Survey question answered by those saying "yes" to having health insurance coverage 


\section{Supplement}

eTable 1. Prevalence of ARB Use in Prior 30 days Among Adults in the United States who Reported Being Diagnosed with Two Select Metabolic, Renal and Cardiovascular Diseases

eTable 2. Trends in Angiotensin Receptor Blocker Use in the US in the Prior 30 Days across NHANES biannual cycles $2005-2018$ Among Adults with Coronary Heart Disease, Stroke, Kidney Disease and Congestive Heart Failure

eTable 3. Prevalence of Angiotensin Receptor Blocker Use in the Prior 30 days Among US Adults with Coronary Heart Disease and Stroke by Social Determinants of Health and Body Mass Index

eTable 4. Prevalence of Angiotensin Receptor Blocker Use in the Prior 30 days Among US Adults with Kidney Disease and Congestive Heart Failure by Social Determinants of Health and Body Mass Index 
eTable 1. Prevalence of ARB Use in Prior 30 days Among Adults in the United States who Reported Being Diagnosed with Two Select Metabolic, Renal and Cardiovascular Diseases ${ }^{\mathrm{a}}$

\begin{tabular}{|c|c|c|c|c|}
\hline Diagnosis & $\begin{array}{c}\text { Total Population } \\
\text { No.b } \\
\text { (millions) }\end{array}$ & $\begin{array}{c}\text { Total Population } \\
\text { \% }{ }^{b} \\
(95 \% \text { CI })\end{array}$ & $\begin{array}{c}\text { ARB Use } \\
\text { No.b }^{\text {(millions) }}\end{array}$ & $\begin{array}{c}\text { ARB Use } \\
\% \text { b }^{b} \\
(95 \% \text { CI })\end{array}$ \\
\hline Hypertension and Diabetes & $\begin{array}{c}3576 \\
(14.671) \\
\end{array}$ & $\begin{array}{c}6.7 \\
(6.4,7.0)\end{array}$ & $\begin{array}{c}916 \\
(3.751)\end{array}$ & $\begin{array}{c}25.6 \\
(23.6,27.6)\end{array}$ \\
\hline $\begin{array}{c}\text { Hypertension and Coronary } \\
\text { Heart Disease }\end{array}$ & $\begin{array}{l}1252 \\
(5.754)\end{array}$ & $\begin{array}{c}2.6 \\
(2.3,2.8)\end{array}$ & $\begin{array}{c}304 \\
(1.311)\end{array}$ & $\begin{array}{c}22.8 \\
(19.4,26.5)\end{array}$ \\
\hline Hypertension and Stroke & $\begin{array}{c}1210 \\
(4.853)\end{array}$ & $\begin{array}{c}2.2 \\
(2.0,2.4)\end{array}$ & $\begin{array}{c}264 \\
(1.089)\end{array}$ & $\begin{array}{c}22.5 \\
(19.4,25.9)\end{array}$ \\
\hline $\begin{array}{c}\text { Hypertension and Kidney } \\
\text { Disease }\end{array}$ & $\begin{array}{c}959 \\
(3.728)\end{array}$ & $\begin{array}{c}1.7 \\
(1.5,1.8)\end{array}$ & $\begin{array}{c}222 \\
(0.901)\end{array}$ & $\begin{array}{c}24.2 \\
(19.9,29.0)\end{array}$ \\
\hline $\begin{array}{c}\text { Hypertension and Congestive } \\
\text { Heart Failure }\end{array}$ & $\begin{array}{c}1095 \\
(4.262) \\
\end{array}$ & $\begin{array}{c}1.9 \\
(1.7,2.1)\end{array}$ & $\begin{array}{c}237 \\
(0.912) \\
\end{array}$ & $\begin{array}{c}21.4 \\
(18.2,25.0) \\
\end{array}$ \\
\hline $\begin{array}{c}\text { Diabetes and Coronary Heart } \\
\text { Disease }\end{array}$ & $\begin{array}{c}599 \\
(2.656) \\
\end{array}$ & $\begin{array}{c}1.2 \\
(1.1,1.4) \\
\end{array}$ & $\begin{array}{c}151 \\
(0.639) \\
\end{array}$ & $\begin{array}{c}24.1 \\
(19.0,30.1)\end{array}$ \\
\hline Diabetes and Stroke & $\begin{array}{c}539 \\
(2.065) \\
\end{array}$ & $\begin{array}{c}0.9 \\
(0.8,1.1) \\
\end{array}$ & $\begin{array}{c}125 \\
(0.470) \\
\end{array}$ & $\begin{array}{c}22.8 \\
(18.5,27.7) \\
\end{array}$ \\
\hline Diabetes and Kidney Disease & $\begin{array}{c}524 \\
(1.889) \\
\end{array}$ & $\begin{array}{c}0.9 \\
(0.8,1.0) \\
\end{array}$ & $\begin{array}{c}133 \\
(0.474) \\
\end{array}$ & $\begin{array}{c}25.1 \\
(20.3,30.6) \\
\end{array}$ \\
\hline $\begin{array}{c}\text { Diabetes and Congestive } \\
\text { Heart Failure }\end{array}$ & $\begin{array}{c}573 \\
(2.199)\end{array}$ & $\begin{array}{c}1.0 \\
(0.9,1.1)\end{array}$ & $\begin{array}{c}130 \\
(0.504)\end{array}$ & $\begin{array}{c}22.9 \\
(18.7,27.7)\end{array}$ \\
\hline $\begin{array}{c}\text { Coronary Heart Disease and } \\
\text { Stroke }\end{array}$ & $\begin{array}{c}289 \\
(1.224)\end{array}$ & $\begin{array}{c}0.5 \\
(0.5,0.6)\end{array}$ & $\begin{array}{c}69 \\
(0.268)\end{array}$ & $\begin{array}{c}21.9 \\
(16.3,28.6)\end{array}$ \\
\hline $\begin{array}{c}\text { Coronary Heart Disease and } \\
\text { Kidney Disease }\end{array}$ & $\begin{array}{c}204 \\
(753)\end{array}$ & $\begin{array}{c}0.3 \\
(0.3,0.4)\end{array}$ & $\begin{array}{c}56 \\
(0.197) \\
\end{array}$ & $\begin{array}{c}26.2 \\
(19.4,34.4)\end{array}$ \\
\hline $\begin{array}{l}\text { Coronary Heart Disease and } \\
\text { Congestive Heart Failure }\end{array}$ & $\begin{array}{c}533 \\
(2.118) \\
\end{array}$ & $\begin{array}{c}0.9 \\
(0.8,1.1) \\
\end{array}$ & $\begin{array}{c}111 \\
(0.448)\end{array}$ & $\begin{array}{c}21.2 \\
(17.1,25.9) \\
\end{array}$ \\
\hline Stroke and Kidney Disease & $\begin{array}{c}192 \\
(0.758)\end{array}$ & $\begin{array}{c}0.3 \\
(0.3,0.4)\end{array}$ & $\begin{array}{c}37 \\
(0.146)\end{array}$ & $\begin{array}{c}19.2 \\
(12.6,28.3)\end{array}$ \\
\hline $\begin{array}{c}\text { Stroke and Congestive Heart } \\
\text { Failure }\end{array}$ & $\begin{array}{c}290 \\
(1.163) \\
\end{array}$ & $\begin{array}{c}0.5 \\
(0.4,0.6) \\
\end{array}$ & $\begin{array}{c}59 \\
(0.236) \\
\end{array}$ & $\begin{array}{c}20.3 \\
(14.7,27.4) \\
\end{array}$ \\
\hline $\begin{array}{c}\text { Kidney Disease and } \\
\text { Congestive Heart Failure }\end{array}$ & $\begin{array}{c}258 \\
(0.936)\end{array}$ & $\begin{array}{c}0.4 \\
(0.4,0.5)\end{array}$ & $\begin{array}{c}52 \\
(0.175) \\
\end{array}$ & $\begin{array}{c}18.7 \\
(12.8,26.5) \\
\end{array}$ \\
\hline
\end{tabular}

\footnotetext{
${ }^{a}$ Diagnoses were obtained from the health questionnaire data via participant self-report in data of 7 biannual cycles (2005-2018)
} 
${ }^{b}$ Values of millions and percent $(95 \% \mathrm{CI})$ are weighted to be nationally representative

eTable 2. Trends in Angiotensin Receptor Blocker Use in the US in the Prior 30 Days across NHANES biannual cycles $2005-2018$ Among Adults with Coronary Heart Disease, Stroke, Kidney Disease and Congestive Heart Failure

\begin{tabular}{|c|c|c|c|c|}
\hline & $\begin{array}{l}\text { Coronary Heart Disease }^{\mathrm{a}} \\
(\mathrm{N}=1,644,7.740 \text { million) }\end{array}$ & $\begin{array}{c}\text { Stroke }^{\mathrm{a}} \\
(\mathrm{N}=\mathbf{1 , 5 9 1 , 6 . 5 8 3} \text { million })\end{array}$ & $\begin{array}{c}\text { Kidney Disease } \\
(\mathrm{N}=1,322,5.784 \text { million})^{\mathrm{a}}\end{array}$ & $\begin{array}{c}\text { Congestive Heart Failure } \\
(\mathrm{N}=1,355,5.458 \text { million })\end{array}$ \\
\hline Biannual Cycle & $\begin{array}{c}\text { ARB Use } \\
\% \\
(95 \% \mathrm{CI})\end{array}$ & $\begin{array}{c}\text { ARB Use } \\
\% \\
(95 \% \mathrm{CI})\end{array}$ & $\begin{array}{c}\text { ARB Use } \\
\% \\
(95 \% \mathrm{CI})\end{array}$ & $\begin{array}{c}\text { ARB Use } \\
\% \\
(95 \% \mathrm{CI})\end{array}$ \\
\hline $2005-2006$ & $\begin{array}{c}12.0 \\
(8.6,16.4)\end{array}$ & $\begin{array}{c}15.5 \\
(9.8,23.7)\end{array}$ & $\begin{array}{c}12.5 \\
(8.0,19.1)\end{array}$ & $\begin{array}{c}15.5 \\
(10.2,22.9)\end{array}$ \\
\hline $2007-2008$ & $\begin{array}{c}19.8 \\
(13.9,27.4)\end{array}$ & $\begin{array}{c}16.7 \\
(12.3,22.2)\end{array}$ & $\begin{array}{c}13.9 \\
(8.9,21.1)\end{array}$ & $\begin{array}{c}19.8 \\
(16.0,24.1)\end{array}$ \\
\hline 2009-2010 & $\begin{array}{c}18.0 \\
(13.4,23.7)\end{array}$ & $\begin{array}{c}16.6 \\
(11.8,22.8)\end{array}$ & $\begin{array}{c}13.9 \\
(10.1,18.8)\end{array}$ & $\begin{array}{c}14.3 \\
(8.1,23.8)\end{array}$ \\
\hline 2011-2012 & $\begin{array}{c}20.0 \\
(14.6,26.8)\end{array}$ & $\begin{array}{c}15.2 \\
(10.1,22.1)\end{array}$ & $\begin{array}{c}19.4 \\
(12.3,29.2)\end{array}$ & $\begin{array}{c}19.6 \\
(12.5,29.5)\end{array}$ \\
\hline 2013-2014 & $\begin{array}{c}18.3 \\
(13.7,23.9)\end{array}$ & $\begin{array}{c}18.4 \\
(12.4,26.3)\end{array}$ & $\begin{array}{c}14.4 \\
(7.8,25.1)\end{array}$ & $\begin{array}{c}17.7 \\
(11.8,25.7)\end{array}$ \\
\hline $2015-2016$ & $\begin{array}{c}25.4 \\
(16.1,37.7)\end{array}$ & $\begin{array}{c}21.1 \\
(14.3,29.9)\end{array}$ & $\begin{array}{c}21.9 \\
(13.8,32.8)\end{array}$ & $\begin{array}{c}21.0 \\
(13.5,31.3)\end{array}$ \\
\hline 2017-2018 & $\begin{array}{c}16.1 \\
(9.5,26.0)\end{array}$ & $\begin{array}{c}17.1 \\
(10.9,25.7) \\
\end{array}$ & $\begin{array}{c}16.8 \\
(10.1,26.7) \\
\end{array}$ & $\begin{array}{c}19.4 \\
(14.2,26.0) \\
\end{array}$ \\
\hline$P$ for trend-value ${ }^{c}$ & 0.160 & 0.929 & 0.568 & 0.865 \\
\hline
\end{tabular}

${ }^{a}$ Diagnoses were obtained from the health questionnaire data via participant self-report in data of 7 biannual cycles (2005-2018)

${ }^{\mathrm{b}}$ Percent $(95 \% \mathrm{CI})$ are weighted to be nationally representative

${ }^{\mathrm{c}}$ Significance for the association of angiotensin receptor blocker use and biannual cycles 
eTable 3. Prevalence of Angiotensin Receptor Blocker Use in the Prior 30 days Among US Adults with Coronary Heart Disease and Stroke by Social Determinants of Health and Body Mass Index

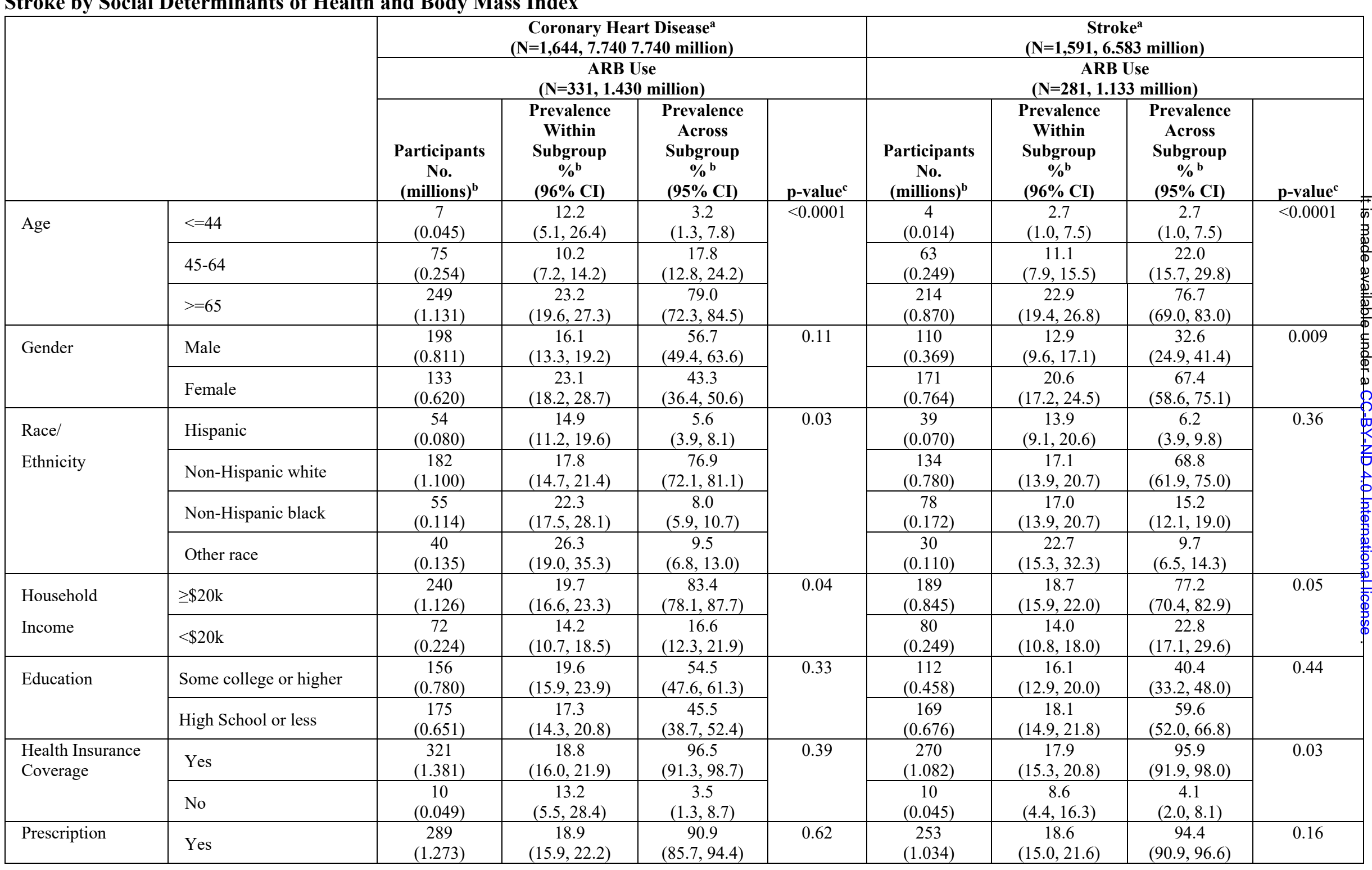




\begin{tabular}{|c|c|c|c|c|c|c|c|c|c|}
\hline $\begin{array}{l}\text { Insurance } \\
\text { Coverage }^{d}\end{array}$ & No & $\begin{array}{c}34 \\
(0.127)\end{array}$ & $\begin{array}{c}21.2 \\
(13.6,31.6)\end{array}$ & $\begin{array}{c}9.1 \\
(5.6,14.3)\end{array}$ & & $\begin{array}{c}19 \\
(0.061)\end{array}$ & $\begin{array}{c}13.1 \\
(7.8,21.2)\end{array}$ & $\begin{array}{c}5.6 \\
(3.4,9.1)\end{array}$ & \\
\hline \multirow[t]{4}{*}{ Body Mass Index } & $\leq 24.99 \mathrm{~kg} / \mathrm{m}^{2}$ & $\begin{array}{c}51 \\
(0.200) \\
\end{array}$ & $\begin{array}{c}13.7 \\
(9.3,19.6)\end{array}$ & $\begin{array}{c}15.2 \\
(10.3,22.0)\end{array}$ & \multirow[t]{4}{*}{0.19} & $\begin{array}{c}42 \\
(0.166) \\
\end{array}$ & $\begin{array}{c}11.4 \\
(8.2,15.6)\end{array}$ & $\begin{array}{c}16.6 \\
(12.1,22.4)\end{array}$ & \multirow[t]{4}{*}{0.01} \\
\hline & $25.00-29.99 \mathrm{~kg} / \mathrm{m}^{2}$ & $\begin{array}{c}99 \\
(0.423)\end{array}$ & $\begin{array}{c}17.6 \\
(13.0,22.0)\end{array}$ & $\begin{array}{c}32.3 \\
(26.9,38.1)\end{array}$ & & $\begin{array}{c}71 \\
(0.269)\end{array}$ & $\begin{array}{c}14.8 \\
(10.7,20.0)\end{array}$ & $\begin{array}{c}26.9 \\
(20.0,35.2)\end{array}$ & \\
\hline & $30.00-39.99 \mathrm{~kg} / \mathrm{m}^{2}$ & $\begin{array}{c}128 \\
(0.586)\end{array}$ & $\begin{array}{c}20.8 \\
(16.4,25.9)\end{array}$ & $\begin{array}{c}44.7 \\
(38.0,51.6)\end{array}$ & & $\begin{array}{c}112 \\
(0.441)\end{array}$ & $\begin{array}{c}21.3 \\
(17.3,25.9)\end{array}$ & $\begin{array}{c}44.2 \\
(36.5,52.1)\end{array}$ & \\
\hline & $\geq 40.00 \mathrm{~kg} / \mathrm{m}^{2}$ & $\begin{array}{c}26 \\
(0.102)\end{array}$ & $\begin{array}{c}20.0 \\
(12.2,31.0)\end{array}$ & $\begin{array}{c}7.8 \\
(4.8,12.3)\end{array}$ & & $\begin{array}{c}24 \\
(0.123)\end{array}$ & $\begin{array}{c}22.0 \\
(13.3,34.2)\end{array}$ & $\begin{array}{c}12.3 \\
(7.5,19.5)\end{array}$ & \\
\hline
\end{tabular}

${ }^{\mathrm{a}}$ Diagnosis was obtained from the health questionnaire data via participant self-report in data of 7 biannual cycles (2005-2018)

${ }^{\mathrm{b}}$ Values of millions and percent $(95 \% \mathrm{CI})$ are weighted to be nationally representative

${ }^{\mathrm{c}}$ Significance for the association of angiotensin receptor blocker use and the parameter

${ }^{\mathrm{d}}$ Survey question answered by those saying "yes" to having health insurance coverage 
eTable 4. Prevalence of Angiotensin Receptor Blocker Use in the Prior 30 days Among US Adults with Kidney Disease and Congestive Heart Failure by Social Determinants of Health and Body Mass Index

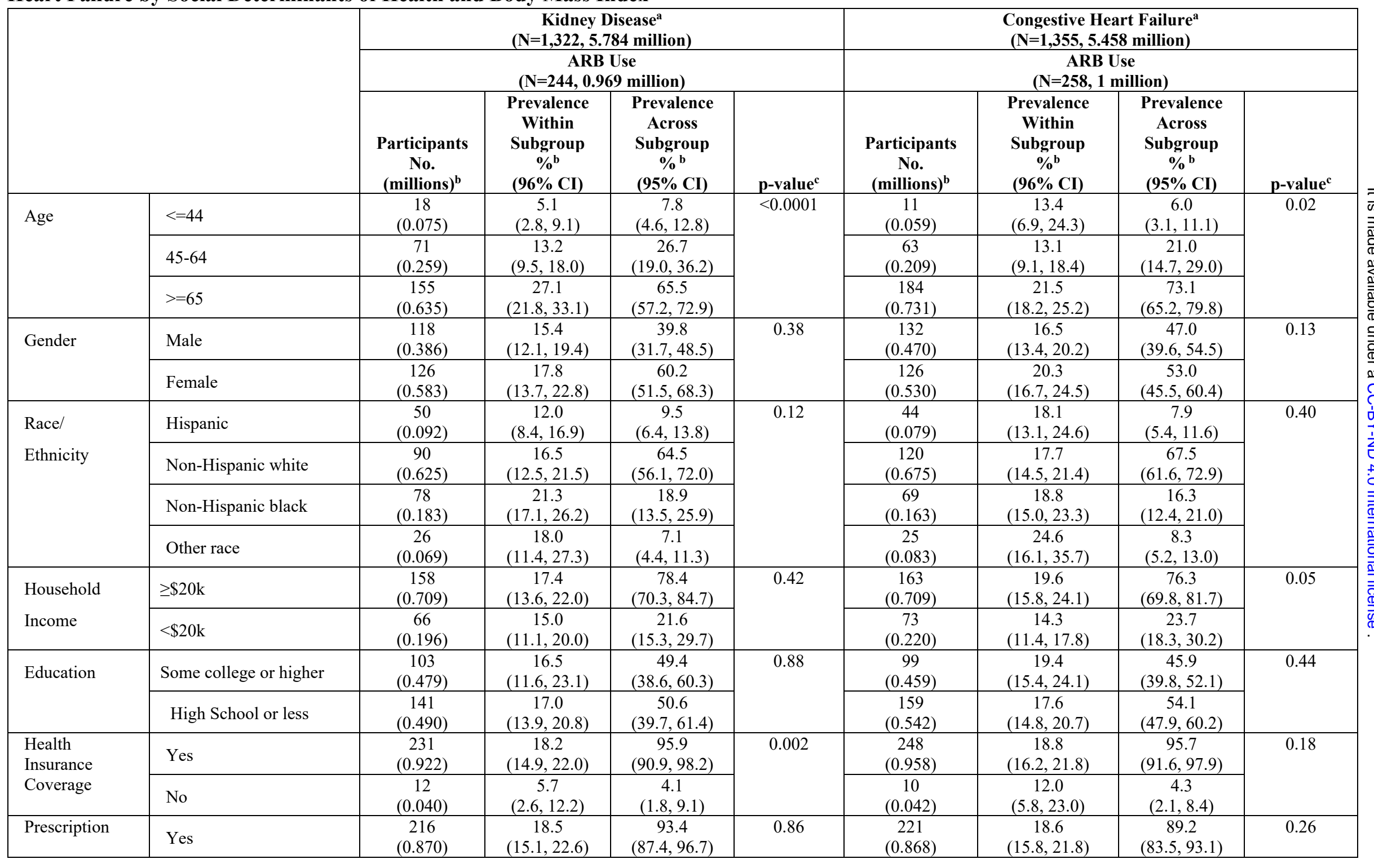




\begin{tabular}{|c|c|c|c|c|c|c|c|c|c|}
\hline $\begin{array}{l}\text { Insurance } \\
\text { Coverage }^{\mathrm{d}}\end{array}$ & No & $\begin{array}{c}16 \\
(0.061) \\
\end{array}$ & $\begin{array}{c}17.6 \\
(10.0,29.2)\end{array}$ & $\begin{array}{c}6.6 \\
(3.3,12.6) \\
\end{array}$ & & $\begin{array}{c}29 \\
(0.104)\end{array}$ & $\begin{array}{c}24.2 \\
(15.7,35.3)\end{array}$ & $\begin{array}{c}10.8 \\
(6.9,16.5)\end{array}$ & \\
\hline \multirow[t]{4}{*}{$\begin{array}{l}\text { Body Mass } \\
\text { Index }\end{array}$} & $\leq 24.99 \mathrm{~kg} / \mathrm{m}^{2}$ & $\begin{array}{c}36 \\
(0.139)\end{array}$ & $\begin{array}{c}10.6 \\
(6.6,16.6)\end{array}$ & $\begin{array}{c}15.2 \\
(9.5,23.4)\end{array}$ & \multirow[t]{4}{*}{0.03} & $\begin{array}{c}31 \\
(0.120)\end{array}$ & $\begin{array}{c}13.5 \\
(8.6,20.4)\end{array}$ & $\begin{array}{c}13.3 \\
(8.4,20.3)\end{array}$ & \multirow[t]{4}{*}{0.02} \\
\hline & $25.00-29.99 \mathrm{~kg} / \mathrm{m}^{2}$ & $\begin{array}{c}62 \\
(0.245)\end{array}$ & $\begin{array}{c}15.9 \\
(11.4,21.8)\end{array}$ & $\begin{array}{c}26.8 \\
(20.6,34.1)\end{array}$ & & $\begin{array}{c}51 \\
(0.202) \\
\end{array}$ & $\begin{array}{c}15.7 \\
(11.8,20.6)\end{array}$ & $\begin{array}{c}22.4 \\
(17.2,28.6)\end{array}$ & \\
\hline & $30.00-39.99 \mathrm{~kg} / \mathrm{m}^{2}$ & $\begin{array}{c}93 \\
(0.402)\end{array}$ & $\begin{array}{c}21.0 \\
(15.3,28.0)\end{array}$ & $\begin{array}{c}44.0 \\
(35.0,53.4)\end{array}$ & & $\begin{array}{c}119 \\
(0.461)\end{array}$ & $\begin{array}{c}23.2 \\
(19.6,27.3)\end{array}$ & $\begin{array}{c}50.9 \\
(43.1,58.6)\end{array}$ & \\
\hline & $\geq 40.00 \mathrm{~kg} / \mathrm{m}^{2}$ & $\begin{array}{c}36 \\
(0.128) \\
\end{array}$ & $\begin{array}{c}23.3 \\
(15.3,33.8)\end{array}$ & $\begin{array}{c}14.0 \\
(8.5,22.1)\end{array}$ & & $\begin{array}{c}34 \\
(0.122) \\
\end{array}$ & $\begin{array}{c}15.5 \\
(9.8,23.7)\end{array}$ & $\begin{array}{c}13.5 \\
(9.1,19.5)\end{array}$ & \\
\hline
\end{tabular}

${ }^{a}$ Diagnosis was obtained from the health questionnaire data via participant self-report in data of 7 biannual cycles (2005-2018)

${ }^{\mathrm{b}}$ Values of millions and percent $(95 \% \mathrm{CI})$ are weighted to be nationally representative

${ }^{c}$ Significance for the association of angiotensin receptor blocker use and the parameter

d Survey question answered by those saying "yes" to having health insurance coverage 